\title{
Review
}

\section{A detailed review of the outbreak of COVID-19}

\author{
Kabita Das $^{1, \dagger}$, M. Shivapriya Pingali ${ }^{2, \dagger}$, Biswaranjan Paital ${ }^{3, \dagger}$, Falguni Panda ${ }^{3}$, Samar Gourav Pati ${ }^{3}$, \\ Anirudh Singh ${ }^{2}$, Pritish Kumar Varadwaj ${ }^{2}$, Sintu Kumar Samanta ${ }^{2, *}$ \\ ${ }^{1}$ Department of Philosophy, Utkal University, Bhubaneswar, 751004 Odisha, India, ${ }^{2}$ Department of Applied Sciences, \\ Indian Institute of Information Technology Allahabad, 211012 Allahabad, India, ${ }^{3}$ Reodx Regulation Laboratory, \\ Department of Zoology, Odisha University of Agriculture and Technology, College of Basic Science and Humanities, \\ Bhubaneswar, 751003 Odisha, India
}

\section{TABLE OF CONTENTS}

1. Abstract

2. Introduction

3. Genetic structure and assembly of SARS-CoV-2

4. Spreading of COVID-19

4.1 Carrier by aerosols

4.2 Water droplets from patients

4.3 Particulate matters (PM2.5 and PM10)

4.4 Waste materials from COVID-19 patients

5. Aggravation of COVID-19 by environmental condition and gases

5.1 Environmental factors

5.2 Environmental gases

6. Therapeutics

6.1 Lopinavir-ritonavir (LPVr)

6.2 Hydroxychloroquine

6.3 Favipiravir

6.4 Remdesivir

6.5 Corticosteroids

7. Current status of vaccine development against COVID-19

8. Impact of COVID-19 on public health, economy, education and social life

8.1 Impact on public health

8.2 Impact on economy

8.3 Impact on education

8.4 Impact on social life

9. Phronetic needs and future challenges for COVID-19

9.1 Phronetic need under the current pandemic

9.2 Future challenges and phronetic need during COVID-19

10. Summary and perspective

11. Author contributions

12. Ethics approval and consent to participate

13. Acknowledgment

14. Funding

15. Conflict of interest

16. References

\section{Abstract}

The disease COVID-19 caused by SARS-CoV-2 is the third highly infectious human Coronavirus epidemic in the $21^{\text {st }}$ century due to its high transmission rate and quick evolution of its pathogenicity. Genomic studies indicate that it is zoonotic from bats. The COVID-19 has led to significant loss of lives and a tremendous economic de- 
cline in the world. Generally, the population at risk of a fatal outcome are the elderly and those who are debilitated or are immune compromised. The fatality rate is high, but now is reduced after the development of preventive vaccine although an effective treatment by drug against the virus is yet to be developed. The treatment is narrowed to the use of several anti-viral drugs, or other re-purposed drugs. Social distancing, therefore, has emerged as a putative method to decrease the rate of infection. In this review, we summarize the aspects of the disease that is so far have come to light and review the impact of the infection on our society, healthcare, economy, education, and environment.

\section{Introduction}

After the outbreak from Wuhan City of China, SARS-CoV-2 has created a major hardship to public health globally since December 2019. The human-to-human transmission of this highly contagious and deadly virus resulted in a pandemic situation in more than 200 countries. The respiratory diseases like Middle East Respiratory Syndrome (MERS) and Severe Acute Respiratory Syndrome (SARS) have already been reported to be caused by the family of coronavirus [1, 2]. The high genome sequence similarity of SARS-CoV-2 with that of bat CoV RaTG13 indicates that both might have originated from the common ancestor [3]. Further, the evolutionary analysis demonstrates that bats could be the natural and common host for SARS-CoV-2, MERS-CoV, and SARS-CoV. It is thought that SARS-CoV-2 was transmitted from bat to humans either directly or through single or multiple intermediate hosts [4, 5]. Generally, the person-to-person spread of this virus occurs through contact with the COVID-19 infected patients or asymptomatic carriers or through contact with the objects/surfaces in close vicinity of the patient. It is reported that this virus gets primarily transmitted among people through respiratory water droplets and/or particulate matters $[6,7]$. In addition, the waste water from the COVID-19 hospitals and home of self-quarantine patients are also predicted by the mediator for the spreading of this virus [8]. Their presence in the faecal matter indicates that these viruses not only survive but also undergo replication in the human digestive tract that creates a high risk for faecal-oral transmission [9]. In addition, there are few cases where the new born of a COVID-19 positive mother was also found to carry SARS-CoV-2 nucleic acid signifies the possibility for mother-to-child transmission of this deadly virus [10]. Studies have demonstrated that the rate of infection and severity of this disease can be influenced by environmental factors like temperature, humidity, and environmental gases like $\mathrm{NO}_{2}$ and $\mathrm{SO}_{2}$ [11]. Due to higher effective reproductive rate $(\mathrm{Re})$, the transmission rate of SARS-CoV-2 (Re of 2.9) is relatively higher than the disease caused by SARS (Re of 1.17) belonging to the same corona family [12]. Due to the lack of drugs with proven efficacy, pre-existing drugs with various combinations have been used to manage the symptoms of COVID19 patients. Since its outbreak, different research groups have been diligently working globally on the development of specific therapeutics and vaccines to treat this disease. Currently, nearly 10 vaccines have received approval for safe and effective use while a large number of vaccines are under preclinical and clinical trials. This outbreak has badly affected the social, industrial, medical, and transport sectors [13]. The initial impact was so horrible that the world had to undergo a phase of lockdowns for a long period of time. All age groups people including children and pregnant women were adversely affected by this infectious disease. People have gradually started working together for breaking the chain of COVID-19 infection. The hard times are sure to pass and a better and peaceful world is slowly regaining. The dangerous virus has given a lesson to society. It is indeed high time to follow Aristotelian phronesis to explore a better phase of life. It is now to rest the mind to overcome the current emergency condition for a stable and peaceful future life. Government and policymakers should be proactive and work together to improve the growth and reduce the economic inequalities.

\section{Genetic structure and assembly of SARS-CoV-2}

The coronavirus family of viruses usually infect humans and other mammals causing respiratory and gastrointestinal infections [14]. Among these, the SARSCoV, MERS-CoV and SARS-CoV-2 (COVID-19) are the most infectious strains. All these belong to the family of Beta Coronaviruses. The genome structure of SARS-CoV2 is very similar to other coronaviruses in its family. The SARS-CoV-2 has a positive sense single stranded RNA as its genetic material.

The RNA of this virus contains 14 ORFs that can encode 27 proteins [15]. These mainly include the Nonstructural proteins (NSPs) that are required for the viral replication and the structural proteins. There are around 16 NSPs that are encoded by the major part of the genome. These are expressed as two polypeptides pp1a and pp1b which undergoes autoproteolysis to give rise to these 16 NSPs [16]. Apart from these, this proteolysis also produces other enzymes that are required for viral replication including the RNA-dependent RNA Polymerase (RdRP) (NSP12), helicase (NSP10) etc. [17]. Among these NSP2NSP6 functions to evading host immunity [18, 19]. The NSP1 prevents the host translation mechanism [17]. The other NSPs either function as proteases, co-factors for RdRP or assist the function of the main NSPs [20, 21]. The structural proteins are responsible to enclose the genome and provide the shape for the virus. These include the Envelope (E), Membrane (M), Nucleocapsid (N) and the Spike (S). The proteins E, N and M are highly conserved and 
are essential for the viral assembly [3, 22]. The S protein helps in the viral entry to the host cell. It contains two domains S1 and S2 which are cleaved by the host TMPRSS. The $\mathrm{S} 1$ domain is mainly responsible for the binding to the angiotensin-converting enzyme 2 (ACE-2) receptor [22]. Thus, most of the therapeutics is targeted against them.

\section{Spreading of COVID-19}

Rolling data by WHO as on $2^{\text {nd }}$ February 2021 indicate that the current pandemic COVID-19 caused by the deadly Coronavirus (SARS-CoV-2) has infected 110,609,979 individuals out of which 2,452,510 have died. American countries are found to be the most affected by the pandemic COVID-19 (Fig. 1). Although the recovery rate is $>90 \%$ in countries such as India, still many countries are struggling to restrict the root causes or the mode of transmission of the disease. The mode of transmission is basically divided into two categories. (1) Direct infection from the infected persons and/or the droplets and, (2) indirect transmission via the contaminated objects i.e., from the objects that carry the virus on them [23]. Besides the mode of infection, it is now established that SARS-CoV2 is detected in many animals including bats, cats, civet cat, snakes, ferrets, dogs, and other domesticated animals [24]. Although it is still controversial whether the virus is zoonotic or man-made in origin, the chance of infections from the above animals to human is highly relevant [25, 26].

Irrespective of the origin, a healthy person can contract the disease by the virus via coughs, sneezes, or even talks or sings of the infected person under the first category [1, 2]. The droplets coming out from the above activities of the patients typically cannot travel more than six feet or almost two meters. SARS-CoV-2 remains viable up to three hours and can remain intact in droplets of minimum size of less than five micron $[27,28]$. Therefore, maintaining social distancing and use of mask has been considered as the strongest mode of prevention from the disease [1, 11, 13, 29-33]. As a preventive mode of action, airborne isolation, room ventilation, and appropriate application of disinfectant (especially in toilets) are strongly suggested to restrict aerosol spread of the virus [34]. Therefore, environmental intervention of the disease along with clinical approaches is quarantined, although more vigorous research on the former aspect is still need to be done to avoid such pandemics in future (Fig. 2).

Under the second category, the objects or surfaces that carry the virus can infect a person indirectly. After the virus is released from the patients as droplets, it usually lands on various surfaces. Also, various objects can have the virus when the patients touch them. The virus remains viable for hours or even for days depending on the surface type (Table 1). When a healthy person touches such contaminated surface(s), the virus can be transferred, carried out and enter the body of a healthy person via mucous membranes present in the eyes, nose, or mouth [35]. Therefore, regular hand washing and use of sanitizers are strongly recommended [1]. Irrespective of the mode of infection, identifying the root causes of the infection and prevention is now becomes the primary area of research until universal vaccination is achieved in the case of SARS-CoV-2. Based on various evidences of the mode of transmission of the virus and the observed $2^{n d}$ wave of the infection noticed in many countries by an evolved and comparatively deadly strain of SARS-CoV-2, the transmission of the virus seems more complicated than that seen in previous pandemics.

\subsection{Carrier by aerosols}

An aerosol (abbreviation of "aero-solution”) is a suspension of fine solid particles or liquid droplets that can travel in air or another gas. It also causes one of the main sources of air pollution and associated health risks (Table 2). The origin of aerosols can be natural or anthropogenic in nature [36]. Examples of natural aerosols are fog, mist, dust, forest exudates and geyser steam and some of the artificial aerosols are mucous droplets while sneezing, coughing etc., smoke, stove smokes etc. [37]. It has been noticed that aerosols act as the main source for direct or indirect infection of COVID-19.

Indoor and outdoor smoke is considered to be accountable for 1.6 million premature deaths per year. Therefore, it is considered as one of the largest ecological issues where human does not feel safe even inside home particularly in poor countries who cannot afford clean fuels for daily cooking (Table 2). Although indoor air pollution is being tackled up to some extent by adopting technologies [11], wide ranges of death under it is really alarming as the graph is rising with time. A comparison from 1990 to 2017 for deaths and associated issues under indoor air pollution indicates that it act as the most leading reason of increasing death risk and associated co-morbidities such as cardiac issues, pneumonia, strokes, hypertension, diabetes and several lung diseases including lung cancers.

As per study, about 1.6 million people died prematurely in 2017 under indoor air pollution related health risks and age groups of $60-69$ and $\geq 70$ are more prone to the risk. This death toll number in 2017 under indoor air pollution was four times more than the number of homicides that was close to 400,000 in 2017. As discussed earlier, countries that suffering from low socio-demographic index top the list. Therefore, in such places, COVID-19 has made an outburst, where steps such as social lockdowns may not work as a successful preventive measure [1, 2].

\subsection{Water droplets from patients}

A geometric or arithmetic spreading rate of the disease COVID-19 has been established with the water droplets sourced from the infected persons. The symptomatic patients are noticed to infect with a high rate as compared to the asymptomatic cases. The water droplets 


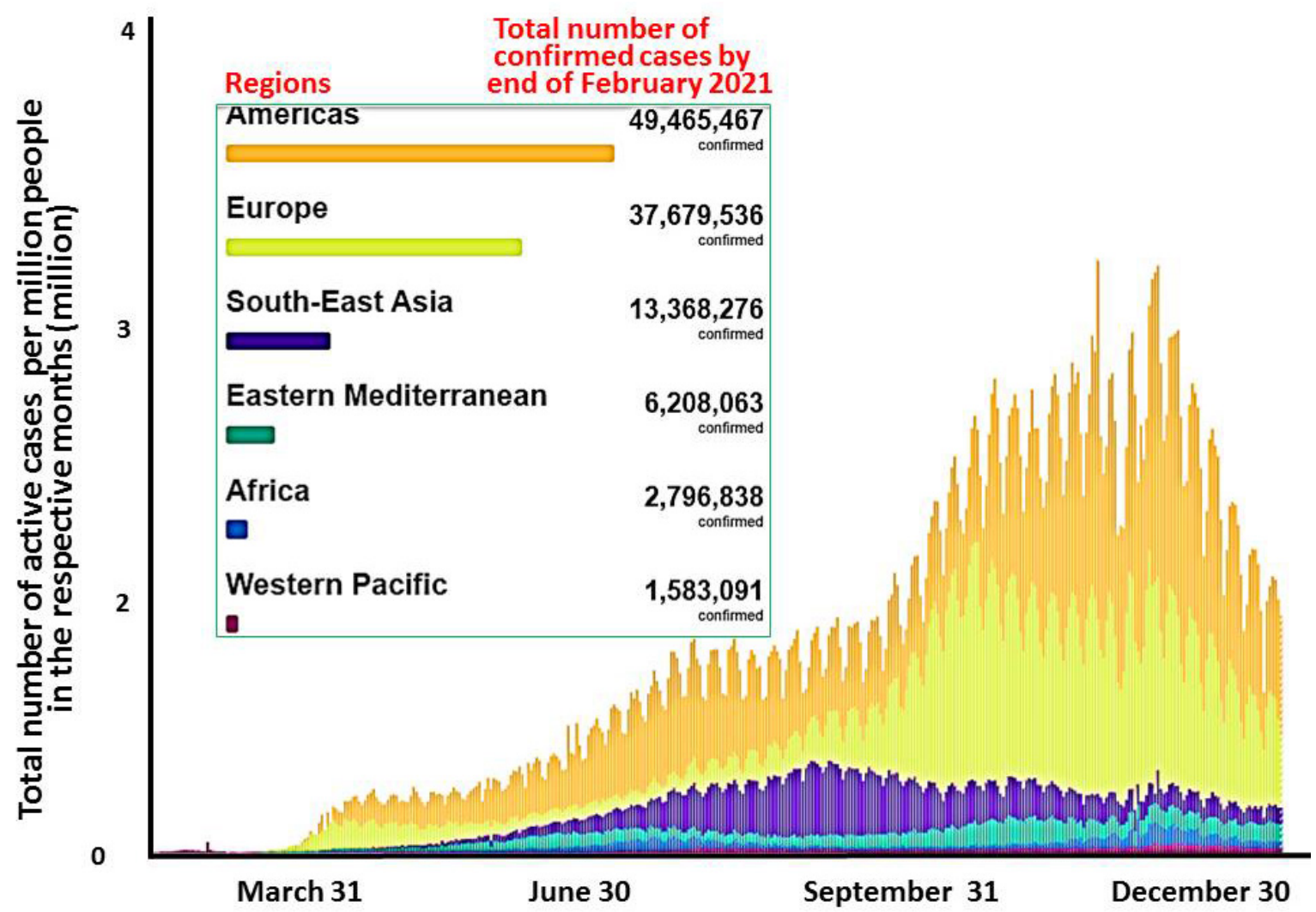

Fig. 1. Global status of COVID-19 outbreak by the end of 2020. As per the latest data obtained from the world health organisation (https://covid19. who.int/) zonation up to the end of the year 2020, the total numbers of confirmed COVID-19 cases per million people are found to be higher in American countries followed by the European and Asian countries (total number indicated as insert).

are released from the patients due to their various activities such as sneezing, coughing, talking and singing $[1,2]$. As per the data from NIH and CDC, many instances are recorded showing the spreading of COVID-19 when healthy subjects came in proximity of asymptomatic cases that even had no idea of the disease with them [38]. Initially, it was hypothesized that only the virus can spread directly as mentioned earlier in this article but it was found that water droplets from the patients (both symptomatic and asymptomatic) can spread the virus rapidly. This has been proved in case studies in Singapore by Wei et al. [16] when the authors had conducted it after conducting research on 243 people within March 2020. Similar reports are also observed from China [39], USA, India etc. [38]. Later on it was accepted by WHO that "SARS-CoV-2 aerosol exposure poses risks of the infection" [11]. Initially maintaining a distance of 13 feet (nearly 4 meters) from each other especially from the infected persons was suggested but later on it was detected that 6 feet distance is sufficient to avoid aerosol especially liquid droplets induced infection of SARS-CoV-2. It is because liquid droplets can't travel much carrying the virus in them [40].

On the other hand, the survivability of SARS$\mathrm{CoV}-2$ in water droplets without host is very limited i.e., for few hours only (Table 1). Normal breathing and talking can create water droplets of size in the range of $<1 \mu \mathrm{m}$ range in majority cases i.e., in $80-90 \%$ cases [41]. Therefore, such water droplets cannot travel much leading its fate to drop on the surface. In human expired air, the aerosols can be of $<$ $10 \mu \mathrm{m}$. It was mentioned by van Doremalen et al. [28] that "the viable in aerosols throughout the duration of our three hours experiment and the infectious titer attenuating by approximately 6-fold over that time frame". They have also notes that the results are similar to those of SARs-CoV-1 i.e., "the half-lives of SARS-CoV-2 and SARS-CoV-1 were similar in aerosols, with median estimates of approximately 1.1 to 1.2 hours and $95 \%$ credible intervals of 0.64 to 2.64 for SARS-CoV-2 and 0.78 to 2.43 for SARS-CoV-1". It has been confirmed that small droplets of $<5 \mu \mathrm{m}$ range can penetrate airways down to the alveolar space where they are more capable of replication and potentially can cause more serious infections. So, particles $<10 \mu \mathrm{m}$ can penetrate past the glottis; while large droplets of diameters of $>20$ $\mu \mathrm{m}$ are described as "a more ballistic trajectory". From the above statement it is concluded that the chance of infection can certainly be prevented by maintaining social distancing from each other both in indoor and, out door as there can be many asymptomatic cases [1, 42-44]. 


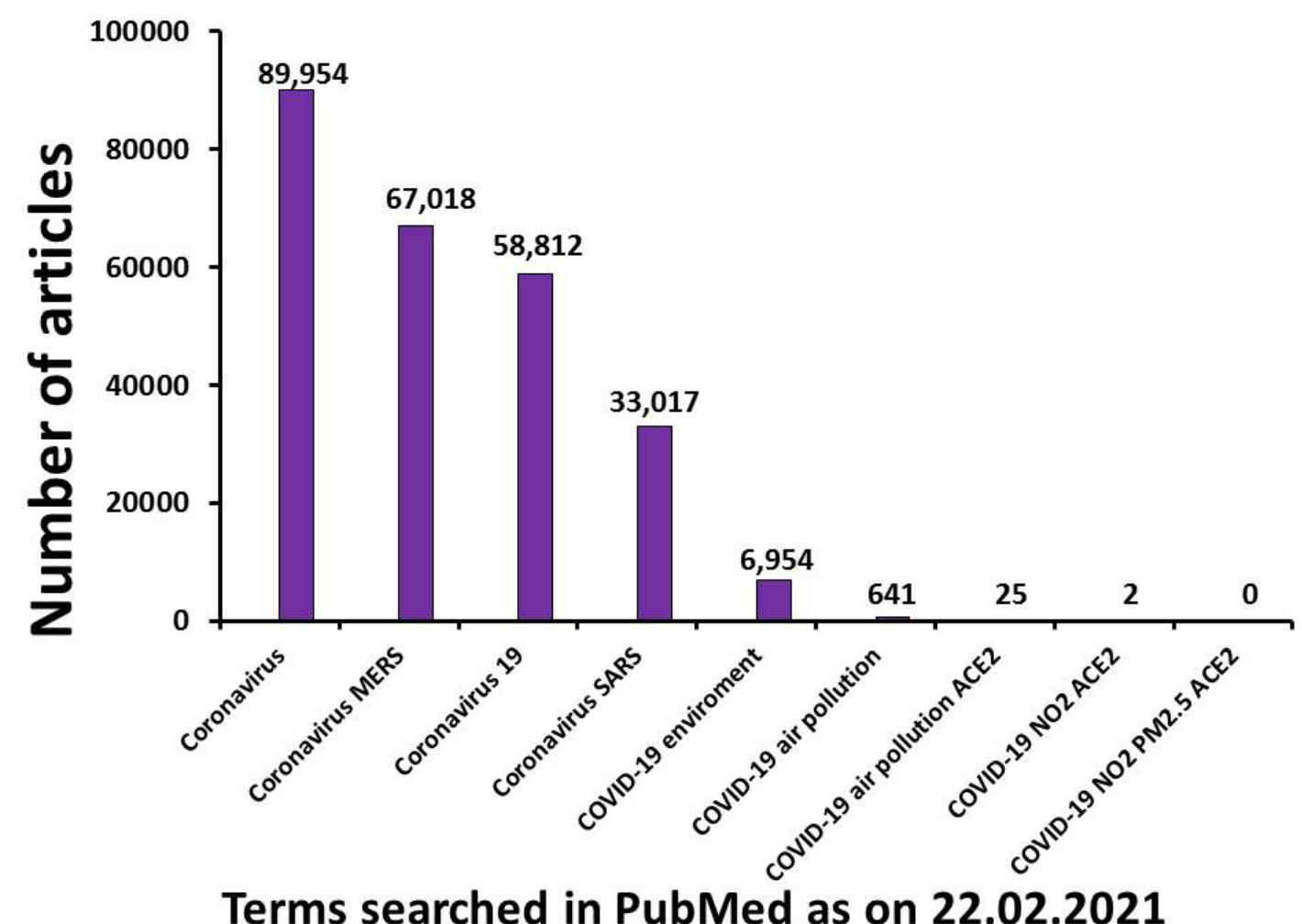

Fig. 2. Total numbers of hit found in PubMed on COVID-19 in relation to environment and ACE-2 expression. Although articles as on 22.02 .2021 on Coronavirus is although approaching 0.08 million, environmental intervention related articles on COVID-19 are very few. Especially, articles on Angiotensin Converting Enzyme 2 (ACE-2) expression that acts as the receptor for the SARS-CoV-2 in relation to air pollution more particularly in relation to NO2 emission and PMs is scanty. Terminologies mentioned in " $\mathrm{X}$ " axis were searched in PubMed as on 22.02 .2021 indicate the gap on research on COVID-19, ACE-2 expression under high $\mathrm{NO}_{2}$ emission and PM2.5 dominated areas.

\subsection{Particulate matters (PM2.5 and PM10)}

Particulate matters (PMs) or the suspended aerosols act as few of the main air pollutants. Particulate matters are the sum of all solid and liquid particles that are found in the suspended in air. They have very dynamic role for acting as cargo for various micro-substances [45, 46]. Particulate matters constitute dust, pollen, soot, smoke, and liquid droplets or any other material originated particles. Such heterogeneous composition of PMs is found to be both organic and inorganic in nature. Therefore, diversity in particle origin, size and composition is observed in PMs. PMs are either directly emitted from the processes such as fuel burning or flying dust or can be indirectly produced from the gaseous pollutants previously emitted to air.

Considering the diversity in average diameter of different PMs, they are classified into two categories. One small category of PMs having average aerodynamic diameter of $2.5 \mu \mathrm{m}$ and the other one is the larger one with the average diameter of $10 \mu \mathrm{m}$. Less than $2.5 \mu \mathrm{m}$ (usually around $0.1 \mu \mathrm{m}$ ) sized PMs are referred as ultra-fine PMs. PM2.5 is called as the fine PMs and PM10 is referred as the course PMs. Many organizations including WHO, have defined PMs as one of the most influential health risk factors. The PMs with an aerodynamic diameter of $\leq 2.5 \mu$ m (PM2.5) in outdoor air pollution in urban cities are studied to be in the range from $\sim 10$ to $\sim 100 \mu \mathrm{g} / \mathrm{m}^{3}$ and PMs with an aerodynamic diameter of $\leq 10 \mu \mathrm{m}$ (PM10) is found to in the range of $>10$ to over $200 \mu \mathrm{g} / \mathrm{m}^{3}$ [47].

The sources of PM2.5 are usually from the combustion of fossil fuels whereas PM10 are generated from the road side dusts. The aerodynamic features of PMs are very important because they determine how PMs are transported in air or their removal strategies. It is because PMs having the same aerodynamic diameter are found to have different dimensions and shapes and vice versa is also true. From aerodynamic properties, their severity of affecting respiratory tracts may also be determined [48-50].

\subsection{Waste materials from COVID-19 patients}

In relation to COVID-19 spreading, many opinions come from experts across the world regarding the environmental surveillance to detect and monitor the disease [51]. Assessment and treatment of waste water from the hospitals and home of patients those are under selfquarantine was monitored for the presence of SARS-CoV2. Many reports have revealed that SARS-CoV-2 RNA is present in waste such as stools from COVID-19 patients, and subsequently the presence of SARS-CoV-2 in wastewaters was recorded worldwide [52-56]. For example, ini- 
Table 1. Stability of CoV-19 and SARS-CoV-1 in aerosols and other materials surfaces.

\begin{tabular}{|c|c|c|c|c|}
\hline \multirow{2}{*}{ Types of material } & \multicolumn{2}{|r|}{ SARS-CoV-2 (CoV-19) } & \multicolumn{2}{|r|}{ SARS-CoV-1 } \\
\hline & Stability & Reduction in infectious titer (from to) & Stability & Reduction in infectious titer (from to) \\
\hline Aerosol & $3 \mathrm{~h}$ & $10^{3.5}$ to $10^{2.7}$ TCID $_{50}$ per liter of air & $3 \mathrm{~h}$ & $10^{4.3}$ to $10^{3.5}$ TCID $_{50}$ per milliliter \\
\hline Plastic & $72 \mathrm{~h}$ & $10^{3.7}$ to $10^{0.6} \mathrm{TCID}_{50}$ per milliliter of medium & $72 \mathrm{~h}$ & $10^{3.4}$ to $10^{0.7}$ TCID $_{50}$ per milliliter \\
\hline Stainless steel & $48 \mathrm{~h}$ & $10^{3.7}$ to $10^{0.6} \mathrm{TCID}_{50}$ per milliliter & $48 \mathrm{~h}$ & $10^{3.6}$ to $10^{0.6}$ TCID $_{50}$ per milliliter \\
\hline Cardboard & $24 \mathrm{~h}$ & - & $8 \mathrm{~h}$ & - \\
\hline Copper & $4 \mathrm{~h}$ & - & $8 \mathrm{~h}$ & - \\
\hline
\end{tabular}

CoV, Coronavirus; h, hours; SARS, Severe Acute Respiratory Syndrome; TCID $_{50}, 50 \%$ tissue-culture infectious dose (Source, van Doremalen et al. [28] under creative common attribution license).

Table 2. Risk of co-morbidity (diseases) under air pollution.

\begin{tabular}{lllccc}
\hline Health outcome & Evidence & Population & Relative risk & Relative risk* & Proof \\
\hline Acute infections in LST & Strong & Children aged 0-4 years & 2.3 & $1.9-2.7$ & SE \\
Chronic OPD & Strong & Women aged $\geq$ 30 years & 3.2 & $2.3-4.8$ & SE \\
& Moderate I & Men aged $\geq 30$ years & 1.8 & $1.0-3.2$ & SE \\
Lung cancer (coal) & Strong & Women aged $\geq$ 30 years & 1.9 & $1.1-3.5$ & SE \\
& Moderate I & Men aged $\geq 30$ years & 1.5 & $1.0-2.5$ & SE \\
Lung cancer (biomass) & Moderate II & Women aged $\geq 30$ years & 1.5 & $1.0-2.1$ & ISE \\
Asthma & Moderate II & Children aged 5-14 years & 1.6 & $1.0-2.5$ & ISE \\
& Moderate II & Adults aged $\geq 15$ years & 1.2 & $1.0-1.5$ & ISE \\
Cataracts & Moderate II & Adults aged $\geq 15$ years & 1.3 & $1.0-1.7$ & ISE \\
Tuberculosis & Moderate II & Adults aged $\geq 15$ years & 1.5 & $1.0-2.4$ & ISE \\
\hline IS, insufficient & evidence; & LST, lower respiratory tract; OPD, obstructive pulmonary disease; S, Sufficient evidence;
\end{tabular}

*data at 95\% confidence interval. The source from Paital and Agrawal [32] under creative common attribution license.

tial studies have confirmed the presence of SARS-CoV-2 RNA in wastewater in The Netherlands [57], France [58], USA [15], and Australia [59]. This has increased the risk of rapid spread of the virus via water bodies. In a recent study in Italy, among the world's worst-affected countries in the COVID-19 pandemic, the presence of SARS-CoV-2 in its wastewaters is also confirmed [60]. This was confirmed by considering twelve influent sewage samples collected between February and April 2020 from Wastewater Treatment Plants in Milan and Rome. The authors had confirmed by molecular tests that $250 \mathrm{~mL}$ water sample can give a good source for the positive test for SARS-CoV-2 [61]. It gives a strong signal for the treatment of waste water and other waste products including the patient's dead body and daily used materials before they are released into the environment.

\section{Aggravation of COVID-19 by environmental condition and gases}

The rate of infection and severity of the disease by the environmental factors especially the pollution or specific gases has been documented [11]. Therefore, emphasizing on the relation between the spreading of the COVD19 and environmental factors is required.

\subsection{Environmental factors}

Many studies are done to correlate between the chance or severity of infection by SARS-CoV-2 and environmental factors such as temperature and humidity. Many virus show a clear correlation for their internalization and propagation in host cell with temperature and humidity. A study done in five countries i.e., Iran, Italy, Germany, Spain, and United States indicated that the average daily variation of environmental factors and new infection was evident [62]. For example, the average temperature and humidity of the infected cities in above countries were found to be ranged from $5{ }^{\circ} \mathrm{C}$ to $11^{\circ} \mathrm{C}$ and 47 to $79 \%$, respectively, and the optimum temperature and humidity for the survival of SARS-CoV-2 in vitro is $4{ }^{\circ} \mathrm{C}$ and 20 to $80 \%$, respectively [23]. In non-of the study area, the temperature had gone below zero degrees Celsius, however, the infection rate was abruptly same or was increasingly recorded in the year 2020. Furthermore, the transmission of the virus was also found to be latitude specific i.e., in the latitude corridor from $30^{\circ}$ to $50^{\circ}$ north (South Korea, Japan, Iran, and North Italy) and it indicates the directional spreading of the disease via direct or indirect mode [63]. Therefore, it was concluded that although a relationship between temperature and the distribution of the virus could be drawn but finally no significant relationship between temperature, humidity, and the virus distribution was illustrated, comparing the global climate and COVID-19 distribution maps $[56,64]$. 


\subsection{Environmental gases}

$\mathrm{NO}_{2}$ and $\mathrm{SO}_{2}$ are two of the major health risk factors. They cause many diseases such as chronic obstructive pulmonary disease (COPD), multiple is chronic heart disease, chronic cardiopulmonary diseases in elderly and children, atopic diseases, lung cancer, nerve disorders and along with air pollutants, they may become fatal for many. In extreme conditions, clinical complications may result in dementia, chronic kidney disease, childhood leukaemia, and multiple organ dysfunction, hyper tension etc. [65-67]. Many co-morbidity conditions under respiratory disorders and COPD are positively correlated with COVID-19 infection, severity and death. Therefore, it is accepted that air pollution has a definite cross talk with COVID-19 or vice versa under the chronic exposure to the emissions of environmental $\mathrm{NO}_{2}$ and $\mathrm{SO}_{2}$.

For example, in India, high air polluted states such as New Delhi (Delhi Municipality area, highly polluted), Gujarat (Industrially highly active and polluted), Maharashtra (Mumbai, highly polluted), Tamil Nadu (Chennai, highly polluted), Telengana (high industrialized), Madhya Pradesh (Industrially active), Uttar Pradesh (Lucknow, Industrially active and highly polluted) and West Bengal (Kolkata), have comparatively high number of COVID-19 positive/death cases $(62,6086 / 10,901,26,1281 / 4,406$, 2,94,537/1,627, 19,9,9982/51,806, 83,2167/12,466, 2,53,763/3,854, 5,91,787/8,716, and 5,60,219/10,251, respectively) as compared to the less air polluted states such as Arunachal Pradesh, Dadar Nagar Haveli, Himachal Pradesh, Manipur, Mizoram, Sikkim and Nagaland (having number of COVID-19 positive/ death 16,775/56, 3,396/02, 57,181/995, 28,818/373, 4,379/10, 5,948/135 and 12,089/91, respectively) as on 23.02.2021 [68].

Above information have clearly demonstrated that air pollution has an intricate direct or indirect relation with COVID-19 spreading and therefore, along with clinical approaches, probably environmental intervention to combat air pollution is also required for controlling COVID19 and any future air borne pandemics [11]. Therefore, countries suffering from such pollution need to rethink to check their air pollution status for a combinatorial medicoenvironmental intervention plans for COVID-19 management [69].

Globally, the emissions of both $\mathrm{NO}_{2}$ and $\mathrm{SO}_{2}$ are found to be positively correlated with the number of COVID-19 new cases and also with the severity of the disease including morbidity. This has been noticed in India, Chia, Italy, and Germany and in many other countries. The main reason is being contributed to the over expression of the ACE-2 that act as receptor for COVID-19 in humans [11]. The death rate under COVID-19 severity has been clearly noticed in many counties including France, Germany, Italy and Spain (Fig. 3). Various mechanisms have been reported behind the cause of the new infection and severity of the COVID-19 cases under air pollution espe- cially under the exposure to high $\mathrm{PMs}, \mathrm{NO}_{2}$ and $\mathrm{SO}_{2}$ emissions (Figs. 4,5)

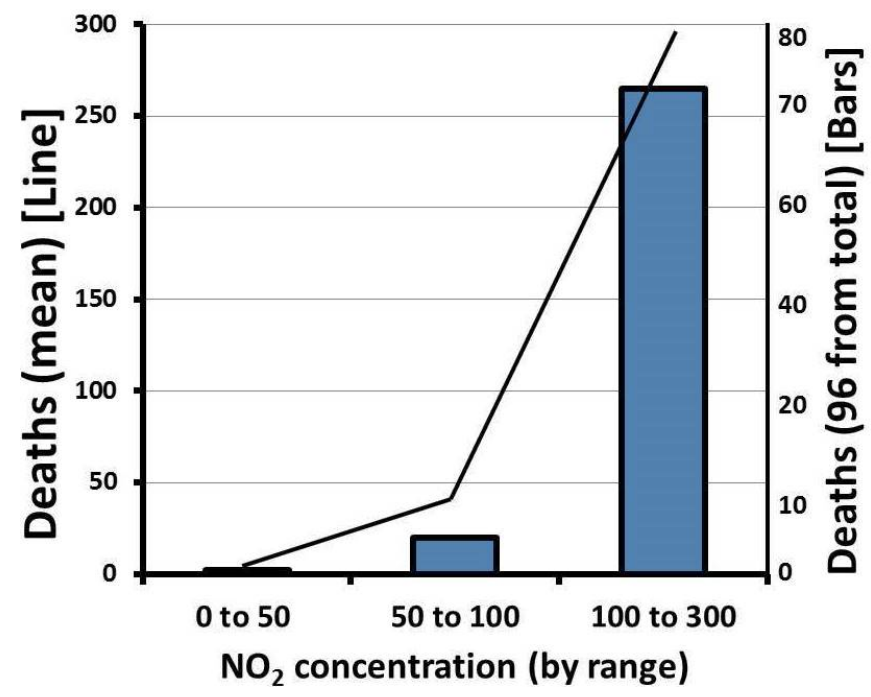

Fig. 3. Effects of NO2 level in COVID-19 deaths in France, Germany, Italy and Spain. Figure (redrawn from Ogen [70] under creative common attribution license), indicates that a strong positive correlation exist between NO2 emissions and COVID-19 deaths in four developed countries. The parentage of death is highly upregulated i.e., up to $80 \%$ with increased in NO2 emissions in the studied area.

\section{Therapeutics}

Since the onset of the pandemic in December 2019, several studies are being performed worldwide to identify a potential drug candidate for the treatment of COVID-19. But it is very well known that this is a very tedious and time-consuming process. Thus, the therapeutic management for COVID-19 has largely focused on the repurposed dugs. Mainly, drugs belonging to anti-viral, antimalarial and immunomodulator classes have highly been used for the COVID-19 treatment. The use of these drugs could reduce the severity and could also curb the symptoms of COVID-19 but there have been several cases of reinfection. This emphasizes the importance of vaccine development and more effective therapeutics against the COVID19.

The drugs used for the COVID-19 treatment mainly function either as inhibitors of viral replication/entry or reduce the inflammatory response of the body in order to prevent tissue damage. Usually, the anti-viral and antimalarial drugs are used to block the entry of the virus or the replication [71, 72]. Thus, these drugs are effective at the earlier stages of the disease. As the disease progresses, the immune system of the body produces inflammatory response that causes tissue damage. This can be counteracted by the administration of corticosteroids [73]. Currently, Remdesivir is the only drug that has been approved for 


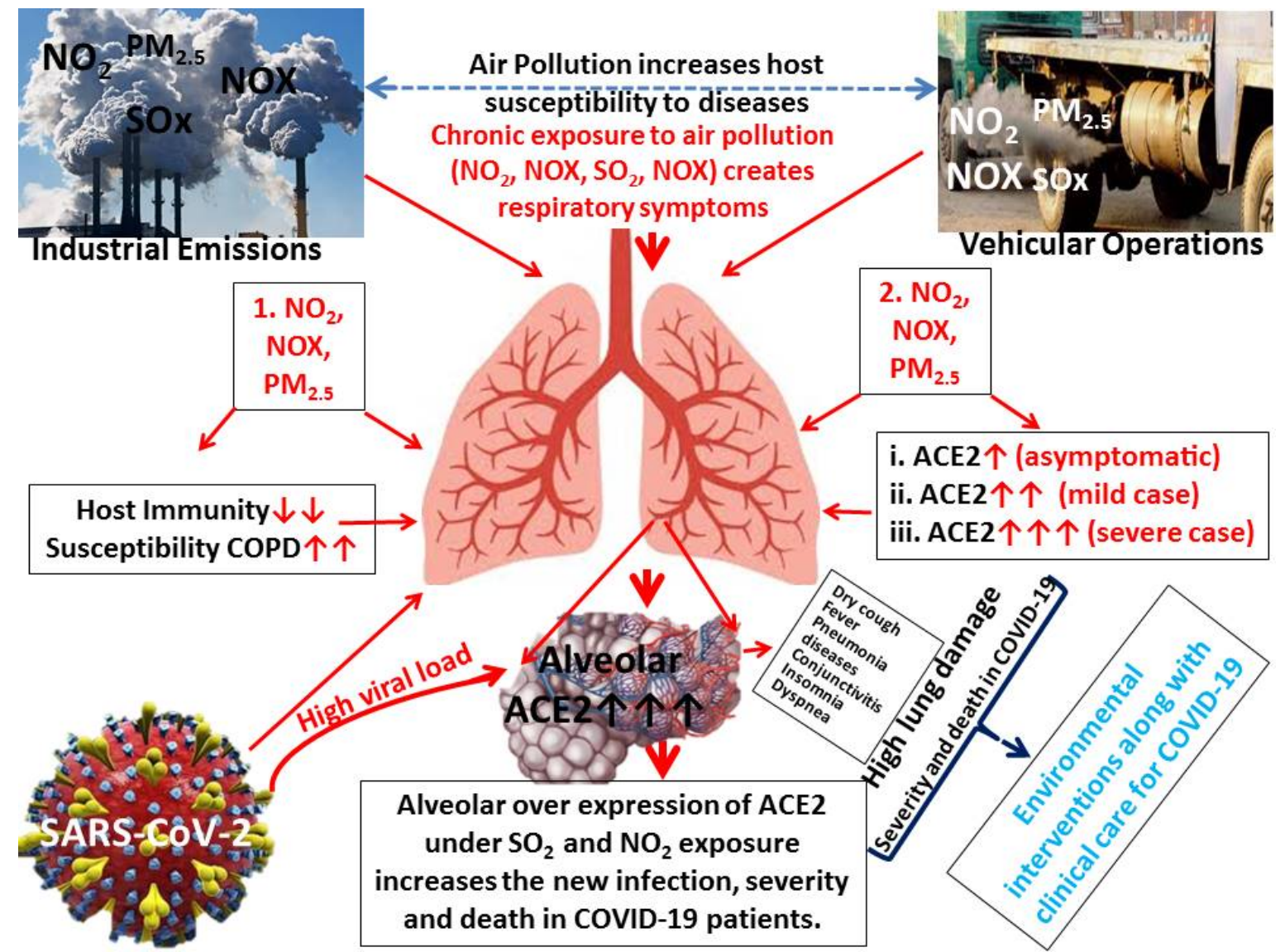

Fig. 4. Air pollution and COVID-19 severity via ACE-2 expression. Depending upon the level of NO2, PM2.5 level mediated Angiotensin Converting Enzyme 2 (ACE-2) expression level in alveolar cells of lungs, the Coronavirus Disease (COVID-19) patients may express the severity into asymptomatic, mild symptomatic and severely symptomatic cases depending on low $(\uparrow)$, moderate $(\uparrow \uparrow)$ and high ( $\uparrow \uparrow)$ expression of ACE-2. Therefore, the environmental co-intervention is suggested along with clinical care to COVID-19 patients where air pollution and COVID-19 have common hot spots. NO2- Nitrogen dioxide, NOX-Oxides of nitrogen, PM2.5-Particulate matter 2.5 (Redrawn after [11] under creative common attribution license).

COVID-19 treatment by the Food and Drug Administration $[74,75]$. It showed better recovery rate and also decreased the recovery time for patients with mild to severe infection who do not require ventilation support [76, 77]. The monoclonal antibodies (i.e Bamlanivimab or casirivimab along with imdevimab) against SARS-CoV-2 can also be used for mild to moderate infections but it is recommended by the FDA only for the emergency use authorization (EUA) for patients who are under the risk of disease progression [75]. In cases of patients who required a respiratory support, dexamethasone is recommended [74, 78].

Since past 1 year, there have been several other drugs that have been used for the COVID-19 treatment. The use of most of these drugs was discontinued due to lack of evidence for their effectiveness among the patients. Here we will discuss little important therapeutics that has been used in COVID-19 treatment emphasizing on their mechanism of action in COVID-19 treatment.

\subsection{Lopinavir-ritonavir (LPVr)}

This combination drug is usually administered in the case of HIV infection in order to decrease the viral load [79]. This is a protease inhibitor hence it was used in the case of COVID-19 in order to target the enzyme 3-chymotrypsin-like protease (3CLpro). The inhibition of this enzyme inhibits the replication and thus prevents the release of the virus from the host cell [80]. The drug proved effective in reducing the fever [81] and the duration of the hospital stay [82] but could not obtain desired outcome in open-label randomised clinical trials [83]. Moreover, questions have been raised for the drug's effectiveness against 3CLpro as its structure is very different from the HIV proteases [84]. Thus, WHO has put off Lopinavir-ritonavir from the solidarity trails for COVID-19 [85].

\subsection{Hydroxychloroquine}

This drug prevents the viral entry into the cells by modifying the environment around the ACE-2 receptor [86]. It was found that when chloroquine was administered, there has been a reduction in the pulmonary 


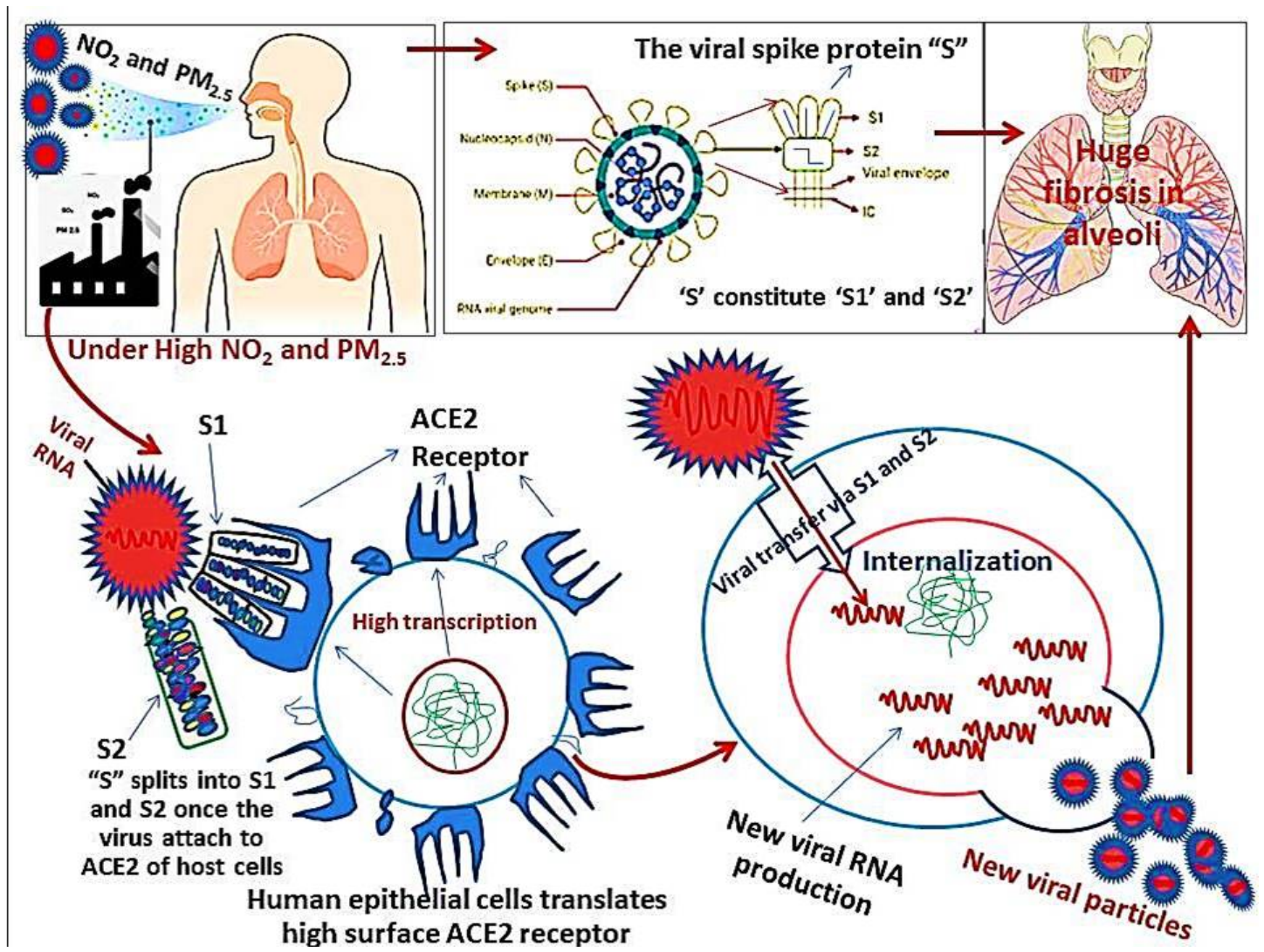

Fig. 5. Possible internalization of the SARS-CoV-2 under high NO2, SO2 and other air pollutants. Air pollution has a positive correlation with Angiotensin Converting Enzyme 2 (ACE-2 that acts as Severe Acute Respiratory Syndrome Coronavirus-2 attachment receptor) expression in human respiratory epithelial cells and that may accelerate the SARS-CoV-2 infection and severity in COVID-19 patients leading to fatality. ACE-2 found to be upregulated under Nitrogen Dioxide (NO2) and Particulate Matter 2.5 (PM2.5) exposure; therefore, air pollution can be considered as an additional factor for causing severity or new infection of COVID-19. Therefore, environmental interventions along with clinical approach are suggested for the management of the severity of COVID-19. ACE-2- Angiotensin converting Enzyme 2, Severe Acute Respiratory Syndrome Coronavirus 2, S-the Spike protein of Severe Acute Respiratory Syndrome Coronavirus-2 that constitutes two parts namely S1 and S2. RNA-Ribonucleic Acid (Figure redrawn from [11] under creative common attribution license).

inflammation [87]. However, this efficiency was not shown when randomized clinical trials were conducted [88]. Hydroxychloroquine was also administered alongside Azithromycin, which again blocks the viral entry by binding to ACE-2 receptor [89]. However, this combination has neither improved the recovery time nor showed any benefit in treating COVID-19 patients [89]. Apart from this, there have been reports of hydroxy chloroquine causing neuropsychiatric side effects that can be so serious that it may cause suicidal tendencies [90, 91]. Thus, both NIH and WHO had dropped HCQ from solidarity trails [92].

\subsection{Favipiravir}

Favipiravir acts by inhibiting the synthesis of viral RNA [93]. Recent clinical trials showed that patients who were administered Favipiravir showed a faster recovery compared to the standard treatment [94, 95]. However, the drug cannot be prescribed to the patients based on this data and further trails are required.

\subsection{Remdesivir}

Remdesivir is a nucleotide analogue that blocks the viral replication by inhibiting the RNA-Dependent RNA polymerase (RdRP). It was repurposed for the case of COVID-19 as it showed very good results in case MERS$\mathrm{CoV}$ [96]. It is recommended for the treatment of mild to moderate COVID-19 infection [73, 97-99]. In a recent study conducted by NIH including 1062 patients, gave a positive result that lead to the emergency use authorization (EUA) for the drug by the FDA (https://Www.Fda.Gov/Me dia/137564/Download). These results were also reflected in the later studies making this the only drug that has been approved for COVID-19 treatment by the FDA [100]. However, care must be taken during administration of this drug as it may cause adverse reactions in liver and kidney [101].

\subsection{Corticosteroids}

These are mainly administered during the severe cases of COVID-19 infection to reduce the inflammation [73]. Dexamethasone is the most prominently used cor- 
ticosteroid and have shown good results by reducing the death rate and also the time for recovery [73]. Thus, WHO has recommended this treatment for the patients with advanced stages of COVID-19 [73].

\section{Current status of vaccine development against COVID-19}

Since it is announced COVID-19 as a pandemic, a large number of scientists had been trying hard for developing potent vaccines to combat SARS-CoV-2. It generally takes a number of years to develop a vaccine with largescale production. Scientists from various parts of the world have been collaborating to bring us vaccines to save lives and end this pandemic. As a result, researchers have made history in 2020 to produce effective and safe COVID-19 vaccines in record time. It is indeed very encouraging to perceive so many vaccines got approved while others are going into development. The various cellular components like spike protein, nucleocapsid protein, membrane protein, whole-cell antigen, and live or attenuated virus have been employed to develop COVID-19 vaccines. However, uses of whole-cell components can be lethal and generally takes a longer time in order to clear the clinical trials. Currently, 89 preclinical vaccines are under animal trials, 70 vaccines are in clinical trials, and 20 have arrived at the final stages of testing with 10 vaccines have got approval for full use. The current status of the vaccine development is given in Table 3. The COVAX Facility will make investments to make a sure at-risk investment in the manufacturing of promising vaccine candidates. As per the allocation framework being developed and guided by WHO, the COVAX Facility will equitably distribute the vaccine doses in order to protect the most at-risk groups across all the participating countries. It is true that vaccines have come delayed to overcome the initial wave of the COVID-19 pandemic; however, these might be beneficial for the subsequent waves to come. These can be useful to handle the post-pandemic situation when this lethal virus may continue to exist as the seasonal flu.

\section{Impact of COVID-19 on public health, economy, education and social life}

Although various diagnostics methods have been developed to detect the infection and different drugs are repurposed along with the discovery of vaccines, COVID-19 yet is the most devastating outbreak continuing in the world (Tables 3-5). The current pandemic situation of COVID-19 has had a drastic impact on the lifestyle of the people residing in more than 200 countries [129]. The governments of several countries had to take strict actions like enforcing lockdowns, social distancing, masks etc. to control the spread of this deadly virus. This had caused a lot of dis- comfort and halted several day-to-day activities of the people. Although, the lockdown restrictions are slowly lifted from the countries the lifestyle has not come to normalcy yet. Here we will discuss the impact of this pandemic on the public health, economy, education and social life.

\subsection{Impact on public health}

The enforcement of lockdown has resulted in lack of socialization in people. Also, people were confined to their homes that contributed to laziness, improper diet and sleep patterns and lack of physical activity. Additionally, there has been a prolonged exposure to the computer/mobile screens as this was the only mode of work and communication. Even educational institutions were teaching using this mode. All these have contributed to the increased risk of diseases that are caused by lack of mental and physical activity [130]. As a result, there has been a tremendous decline in the physical activity i.e., from $540 \mathrm{~min} /$ week to $105 \mathrm{~min} /$ week and the screen time has sharply increased by around 30 hours per week. Looking at this, the international fitness centres have been trying hard to enlighten the people about the importance of physical activity in improving the immunity and mental health of people [131].

Currently, this situation is has improved to a certain extent after the lockdown has been lifted by the countries. But the use of masks, social distancing etc. is still enforced. Also, the schools and workplaces are working with very low strength of people. Thus, it can be said that the life to normalcy is still a long journey to make.

\subsection{Impact on economy}

The shutdown of industries, halt in the supply chain and the immediate requirement to meet the health emergency due to COVID-19 had severely hit the economy of several countries. This situation demanded a huge investment from the governments to meet the necessity of basic healthcare equipment, hospital beds, ventilators etc. Also, the non-essential industries were closed due to the lockdown thus creating an increased demand for certain goods which ultimately increased their cost. This shut down has also impacted several national and multinational companies due to which the employees were deprived of their jobs. Also, the low-skilled workers were affected by this pandemic as there was no work available. All these factors have contributed to a decreased cash flow in the market which had in turn impacted the economic growth rate [132]. Post-lockdown, this situation is slightly better but the loss incurred is too large to compensate it just by resuming the manufacturing. Hence, governments have to work up on better economic policies to improve their economic condition [133]. Unlike earlier, there must be more focus on healthcare and research to reduce the loss and be in a position to provide better services to the people in case of such conditions. 
Table 3. Current updates on COVID-19 vaccine.

\begin{tabular}{|c|c|c|c|c|c|}
\hline Vaccine Name & Type of vaccine & Involve institution & Involve Country & Current Status & Characteristics \\
\hline mRNA-1273 & m-RNA & Moderna, BARDA, NIAID & USA, Canada & Approved & $\begin{array}{l}\text { mRNA-1273 compound develop stabilized prefusion spike } \\
\text { protein of virus [102]. }\end{array}$ \\
\hline Sputnik V & Non replicating virus & $\begin{array}{l}\text { Gamaleya Research Institute, Acellena Contract Drug I } \\
\text { Research and Development }\end{array}$ & Russia & Approved & Virus vector which is not able to replicate into body [102, 103]. \\
\hline EpiVacCorona & Peptide vaccine & $\begin{array}{l}\text { Federal Budgetary Research Institution State Re- F } \\
\text { search Center of Virology and Biotechnology }\end{array}$ & Russia & Approved & Artificially synthesized peptide of virus [104]. \\
\hline Covaxin & Inactivated vaccine & Bharat Biotech; National Institute of Virology & India & Approved & $\begin{array}{l}\text { Covaxin vaccine is attenuated virus where Alhydroxiquim-II } \\
\text { works as adjuvant to build immunity against it [105]. }\end{array}$ \\
\hline BNT162b2 & m-RNA & Pfizer, BioNTech; FosunPharma & Multinational & Approved & m-RNA code for the spike protein of virus [102]. \\
\hline BBIBP-CorV & Inactivated vaccine & $\begin{array}{l}\text { Beijing Institute of Biological Products; China Na- } \\
\text { tional Pharmaceutical Group (Sinopharm) }\end{array}$ & China & Approved & $\begin{array}{l}\text { Virus has been attenuated through } \beta \text {-propiolactone compound } \\
\text { [106]. }\end{array}$ \\
\hline CoronaVac & Inactivated vaccine & Sinovac & China & Approved & $\begin{array}{l}\text { Virus has been attenuated through } \beta \text {-propiolactone compound } \\
\text { [107]. }\end{array}$ \\
\hline Convidicea (Ad5-nCoV) & Recombinant Virus & Tongji Hospital & China & Approved & $\begin{array}{l}\text { Adenovirus type } 5 \text { has been used as vector to express SARS- } \\
\text { Cov2 spike protein in host and it is replication deficient [108]. }\end{array}$ \\
\hline Ad26.COV2.S & Recombinant Virus & Johnson \& Johnson & USA & Approved & $\begin{array}{l}\text { Replication incompetent adenovirus type } 26 \text { has been used as } \\
\text { vector to produce spike protein of SARS-CoV2 [109]. }\end{array}$ \\
\hline AZD1222 & Recombinant Virus & Oxford university and Serum institute of India & Britain and India & Approved & $\begin{array}{l}\text { Adenoviral vector ChAdOx1 is replication deficient virus } \\
\text { which contain spike protein gene of SARS-CoV-2 [110]. }\end{array}$ \\
\hline $\begin{array}{l}\text { Bacillus Calmette-Guerin } \\
\text { (BCG) vaccine }\end{array}$ & Live-attenuated vaccine & University of Melbourne & Australia & Phase 2/3 & $\begin{array}{l}\text { It is primarily used for developed immune response against TB } \\
\text { [111]. }\end{array}$ \\
\hline ZF2001 & Recombinant vaccine & $\begin{array}{l}\text { Anhui ZhifeiLongcom Biopharmaceutical, Institute } \\
\text { of Microbiology of the Chinese Academy of Sciences }\end{array}$ & Various & Phase 3 & $\begin{array}{l}\text { Receptor binding domain of spike protein used as to develop } \\
\text { immunity into host. }\end{array}$ \\
\hline INO-4800 & Plasmid DNA & Inovio Pharmaceuticals & USA & Phase $2 / 3$ & $\begin{array}{l}\text { Intramuscular injection of plasmid DNA which carry spike pro- } \\
\text { tein gene [112]. }\end{array}$ \\
\hline NVX-CoV2373 & Nanoparticle Vaccine & Novavax & Novavax & Phase 3 & $\begin{array}{l}\text { Formation of spike protein in host that leads to immunogenic } \\
\text { in body. Where Matrix-M nanoparticles act as adjuvant. [113]. }\end{array}$ \\
\hline ZyCoV-D & DNA vaccine (plasmid) & ZydusCadila & India & Phase 3 & $\begin{array}{l}\text { DNA plasmid consist of spike protein gene. Which leads to } \\
\text { formation of neutralizing IgG antibodies [114]. }\end{array}$ \\
\hline
\end{tabular}


Table 3. Continued.

\begin{tabular}{|c|c|c|c|c|c|}
\hline Vaccine Name & Type of vaccine & Involve institution & Involve Country & Current Status & Characteristics \\
\hline CVnCoV & mRNA-based vaccine & CureVac; GSK & CureVac & Phase 2b/3 & $\begin{array}{l}\text { mRNA is synthesized full length of spike protein that is formu- } \\
\text { lated with lipid nanoparticles [115]. }\end{array}$ \\
\hline VIR-7831 & Plant-based adjuvant vaccine & Medicago; GSK; Dynavax & Medicago & Phase $2 / 3$ & Monoclonal antibody specific for spike protein [116]. \\
\hline No name announced & Adenovirus-based vaccine & ImmunityBio; NantKwest & & Phase $2 / 3$ & $\begin{array}{l}\text { adenovirus vector hAd5 deliver spike protein and nucleocap- } \\
\text { sid for generation of immunity [117]. }\end{array}$ \\
\hline UB-612 & Multitope peptide-based vaccine & COVAXX & $\begin{array}{l}\text { United Biomedical I } \\
\text { Inc. (UBI) }\end{array}$ & Phase $2 / 3$ & $\begin{array}{l}\text { Use the epitope of S2, M and N site of virus to bind with MHC1 } \\
\text { and MHC2 of T-cells for activation [118]. }\end{array}$ \\
\hline Abdala (CIGB 66) & Protein subunit vaccine & Finlay Institute of Vaccines & Cuba & Phase 2 & Yest was used to form RBD with alumina adjuvents [119]. \\
\hline BNT162 & mRNA-based vaccine & Pfizer, BioNTech & $\begin{array}{l}\text { Multiple study sites in } \\
\text { Europe, North Amer- } \\
\text { ica and China }\end{array}$ & Phase 1/2/3 & m-RNA code for the spike protein of virus [120]. \\
\hline AdCLD-CoV19 & Adenovirus-based vaccine & Cellid; LG Chem & Korea $\quad \mathrm{I}$ & Phase $1 / 2 \mathrm{a}$ & $\begin{array}{l}\text { Replication-defective human adenovirus type } 5 / 35 \text { vector ex- } \\
\text { press spike protein [122]. }\end{array}$ \\
\hline Nanocovax & $\begin{array}{l}\text { Recombinant vaccine (Spike pro- } 1 \\
\text { tein) }\end{array}$ & Nanogen Biopharmaceutical & Vietnam & Phase 1/2 & Recombinant spike protein with $\mathrm{AlPO}_{4}$ adjuvant [123]. \\
\hline EuCorVac-19 & nanoparticle vaccine & EuBiologics & South Korea & Phase $1 / 2$ & Spike protein with adjuvant [124]. \\
\hline Mambisa (CIGB 669) & Protein subunit vaccine & Finlay Institute of Vaccines & Cuba & Phase 1/2 & $\begin{array}{l}\text { It is a subunit vaccine that use the AgnHB protein as an antigen } \\
\text { [119]. }\end{array}$ \\
\hline IIBR-100 & $\begin{array}{l}\text { Recombinant vesicular stomatitis } \\
\text { virus (rVSV) vaccine }\end{array}$ & Israel Institute for Biological Research & Israel & Phase $1 / 2$ & $\begin{array}{l}\text { vesicular stomatitis virus (VSV) is recombinant virus which } \\
\text { express spike protein on their surface [124]. }\end{array}$ \\
\hline No name announced & SF9 cell vaccine candidate & West China Hospital, Sichuan University & China & Phase $1 / 2$ & Viral gene (spike protein) express in insect cell line [125]. \\
\hline Soberana 1 and 2 & Monovalent/conjugate vaccine & Finlay Institute of Vaccines & Cuba & Phase 1/2 & RBD of spike protein conjugate with tetanus toxoid [126]. \\
\hline VLA2001 & Inactivated vaccine & $\begin{array}{l}\text { Valneva; National Institute for Health Research } \\
\text { (NIHR) }\end{array}$ & Britain & Phase 1/2 & $\begin{array}{l}\text { Whole cell used as antigen where alum and CpG are adjuvants } \\
\text { [127]. }\end{array}$ \\
\hline No name announced & Adjuvanted protein subunit vaccine & CEPI & & Phase $1 / 2$ & Inactive virus was used for development [128]. \\
\hline
\end{tabular}


Table 4. Details of various diagnosis methods used for COVID-19.

\begin{tabular}{llll}
\hline Source of sample & Diagnostic tools & Mode & Merits \\
\hline $\begin{array}{l}\text { Nasopharyngeal swab } \\
\text { Stool }\end{array}$ & RT-PCR & Nucleic Acid amplification for viral & $\sqrt{ }$ Targets different components of viral genome \\
Tissue sample & RT-PCR & DNA & $\sqrt{ }$ Increased accuracy \\
Lungs & X-ray/CT-Scan & Inter/Intra lobular septal thickening and $\sqrt{ }$ Check Erroneous infection severity \\
& Antibody based rapid detection tools IgG/IgM antibody detection & $\sqrt{ }$ Track lung recovery \\
Venepuncture blood & & & $\sqrt{ }$ Early accessible \\
& & bronchovesicular thickening & $\sqrt{ }$ \\
Blood \& Aid in tracing infected persons contacts & Antibody detection & $\sqrt{ }$ Detection of past exposure \\
\hline
\end{tabular}

\subsection{Impact on education}

The education institutions not only impart knowledge and understanding in students but also help them to develop inter-personal skills. These are required to give an overall development for the students. They impart discipline, patience and also improve their emotional well-being. The lockdown in several countries have impacted this routine in children. Hence education institutions have started distant learning programme minimize the educational loss among the students. But this online mode of education has nothing to do with other important aspects that contribute to the over-all development. Also, these programmes depend on internet, mobile/laptops which are not available in remote and economically weaker sections. This might create a socio-economic gap in the society [134]. This has also impacted the employment in current graduate as most of them were not given a job. This again may affect their mental health, decrease confidence and may lead to depression in the younger generation [134]. Post-Lockdown, the schools and educations institutions were the last to open on a full-fledged basis. However, it was not mandatory for the students to attend the school. Even the parents are reluctant to send their children to school due to the fear of infection. Thus, vaccines are the only options that can improve the situation in this area.

\subsection{Impact on social life}

The rapid spread of the virus has severely affected the social life of the people during the pandemic $[29,135,136]$. The people were confined to their houses and strict actions were taken to avoid any gatherings in the public. Also, the sudden announcement of lockdown had given no time for the people to get back to their families causing loneliness, worry and anxiety. This situation particularly impacted the elderly people [137] and people who lead a very social life. Additionally, the places of entertainment like restaurants, theatres, shopping malls etc. have been shut down which can further increase the stress and anxiety levels in the people [132]. Although these restrictions have been lifted, visiting these places or involving in any type of public gathering is very risky since the pandemic has not subsided yet.

\section{Phronetic needs and future challenges for COVID-19}

In a society, every individual and every organization is involved in making hundreds of decisions and experiences every day. The decisions people make are reflection of their values and beliefs, and they are always directed towards a specific purpose $[138,139]$. That purpose is to find a better life and could be a mass avoidance of a disease including the current pandemic COVID-19. Individual never develop their character, and values in isolation [140]. They need society where they explore their thoughts, character and experiences which are extremely needed under the current crisis. The better mankind produces good thoughts and experiences the better society which can create a knowledge based platform to avoid global issues [141-144]. But when people act unwisely, their fellow beings suffer, and so can society and this is the most important issue to follow the rules and regulations set to avoid the spreading of COVID19. To deal with many societal problems caused under the pandemic and to find out the measures, the concept phronesis given by the famous philosopher Aristotle seems essential at this pandemic time [145]. The phronesis is one's ability to perceive the situation, to have the appropriate feelings or desires about it, to deliberate about what is appropriate in the given circumstances and to act [146]. Therefore, it is a master virtue to resolve many societal issues and to find the purpose to lead a better life under the COVID-19 caused crisis. It is not a kind of theoretical knowledge rather a kind of practical one and acquires through experience and practice [140, 147, 148]. It is the virtue about well performing a particular social practice such as maintaining social distancing, wearing mask and adopting regular hand washing and sanitization practices to avoid SARS-CoV-2. Being a good friend or parent or teacher or doctor or soldier or citizen and that meant figuring out the right way to do the right thing in a particular circumstance, with a particular person with a particular time like above activities is the current need of the day in sectors such medical, academics, institutes, and industries where gathering is common [11, 146]. 
Table 5. Drugs proposed for Repurposing.

\begin{tabular}{|c|c|}
\hline Drug & Mode of action \\
\hline Remdesivir & Nucleoside analog and inhibits viral RNA \\
\hline Chloroquine or hydroxychloroquine & Interact with ACE-2 and stops virus to invade, causes immune suppression \\
\hline Galidesivir & Antiviral \\
\hline Ribavirin & Antiviral \\
\hline Amodiaquine & Anti-parasitic agent \\
\hline Darunavir & Antiviral \\
\hline Lopinavir & Binds to main protease \\
\hline Ritonavir & Binds to main protease \\
\hline Imatinib & Kinase signaling inhibitor \\
\hline Leflunomide & Inhibits the process of replication \\
\hline Favipiravir & Antiviral, target RdRp \\
\hline Glucocorticoids & Suppresses the immune response \\
\hline Anakinra & Blockage of IL-1 receptor and its downstream signalling pathways \\
\hline Luteolin & Binds to main protease \\
\hline Ruxolitinib & Suppress immune system and JAK inhibition \\
\hline Arbidol & Block trimerization of the spike glycoprotein \\
\hline Azithromycin & Antibiotics \\
\hline Baricitinib & Blocks viral invasion \\
\hline Amantadine & Alters the Cathepsin L functional environment which may decrease the viral replication \\
\hline Tocilizumab & It controls high levels of cytokines (specially IL6) and block the IL-6 receptor and further cascading reaction \\
\hline Thalidomide & Reduces of cytokines storm \\
\hline
\end{tabular}

\subsection{Phronetic need under the current pandemic}

In this present time, the current society suffers in different ways due to unwisely act. And the highly virulent SARS-CoV-2 that affected the whole world seems as the outcome of unwise human action. As this virus started from China and slowly grasped the whole world and major portion of the society is shocked in just a matter of six months $[1,2,29]$. The virus had contagious and spread very fast, leading WHO to declare it as global pandemic. The major part of the world shutdown the industries, schools, market and many social events [1, 2, 29]. Millions of people leading in a painful period of uncertainty and anxiety as the pandemic has broken their part of normal life and ruptured their work. So, the current society is imbalanced, people suffer with this unprecedented virus COVID-19 and live with anxiety, depression, and uncertainty that came from this contagious virus SARS-CoV-2 [148]. It affected the mega portion of the society. So, it is the time to exercise this operative virtue phronesis at individual level, at public level, at country level and government levels to overcome from the uncertainty. Globally, many governments have took the restrictive measures to control the pandemic situation that has led to a massive global public health campaign to slow the spread of the virus by increasing hand washing, reducing face touching, wearing masks and maintaining physical distancing in public. While efforts to develop pharmaceutical interventions such as drug development and vaccination against COVID-19 are under way, the social and behavioral sciences can provide valuable insights for managing the pandemic and its impacts [149].
People feel a difference between these measures and their freedom of normal lives which is a very challenging under the current situation. People should follow all the guidelines taken by government under this crisis period. But the question arises here that why should people collaborate with the restrictions. The phronetic agent as proposed by Aristotle [150] is to develop ability to correctly and cautiously follows what is beneficial for individual as well as for the society. By the help of phronesis one is able to rationally grasp which actions are good and bad for mankind. For example, it would be bad for every individual to be infected with SARS-CoV-2 and to infect others in current period. One may not know whether he/she is healthy or an asymptomatic infected case that has not been tested. It would therefore need to follow phronetic act at the individual level, which is not possible under the lack of knowledge, to practice physical distancing [151].

At present Government have been continuously taking numerous measures to save mankind in this current pandemic crisis such as to help policy makers, public, leaders, in time to time, to better comprehend how to manage the anxiety, panic, threats, and uncertainty and create reflective thinking, moral thinking and cooperation in different levels. Government has taken the phronetic decisions like to improve scientific communication that helps individual and collective interests, to give support to every mankind in the form of healthy life [152]. The present crisis was covered on unsettled tensions between mankind and technology, between human being and the planet, between the haves and the have-nots. These tensions were already the causatives to a new generation of inequalities pertaining to 


\section{REALIZE WHAT YOU CAN CONTROL}

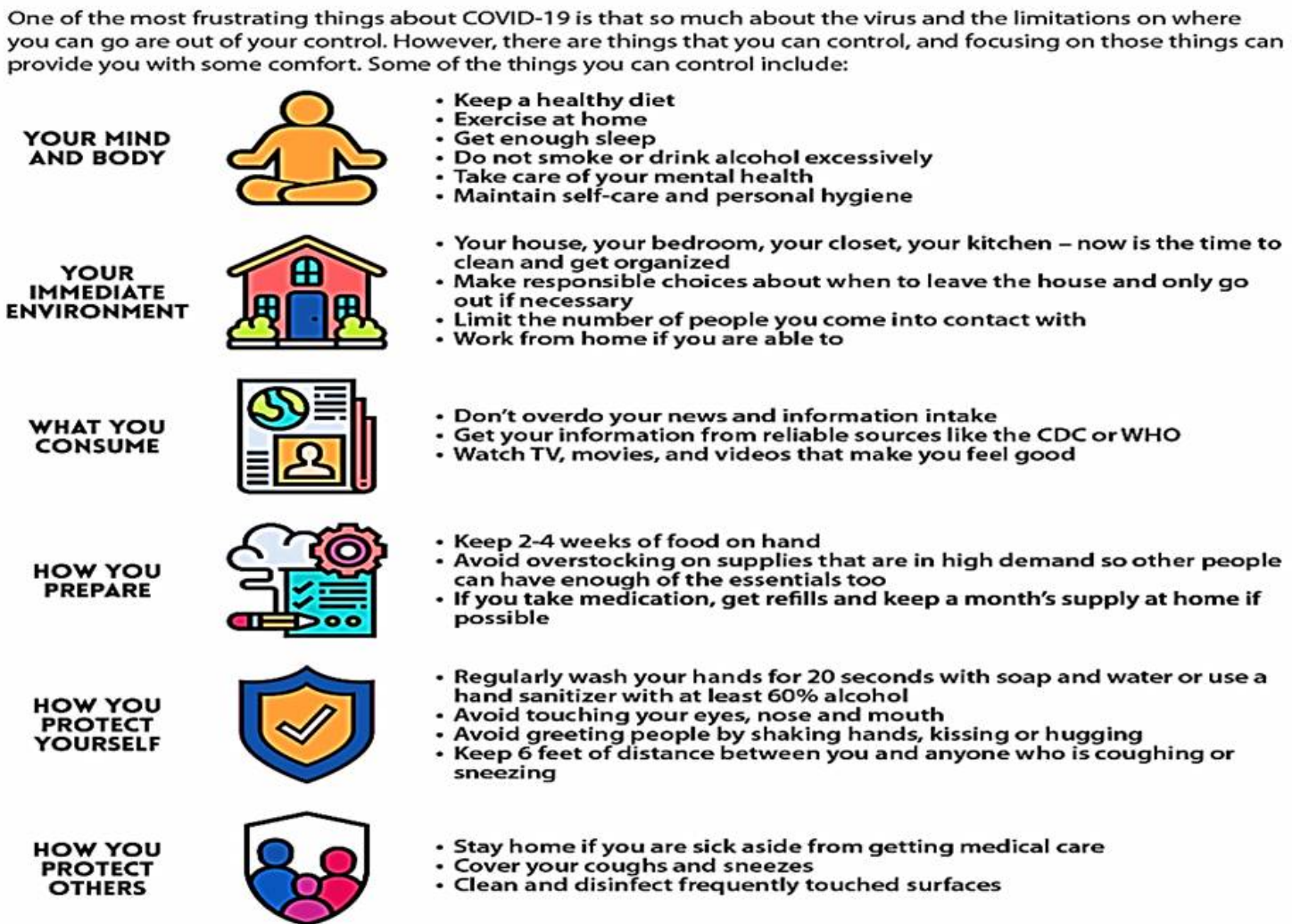

Fig. 6. How to protect one self and others from this pandemic situation (Source. Google images under creative common attribution license).

the enhanced and new necessities of the $21^{\text {st }}$ century [153]. But the response to the crisis can shape how those tensions are addressed and whether inequalities in human development are reduced [154]. The phronesis is the key term to develop the ability and capabilities, by taking the wise decisions, moral support, and optimistic work culture positive way to enhance the mind set in this unprecedented situation under COVID-19.

A phronetic person or a phronetic decision always take into account the capabilities approach to document the severity of the unfolding human development crisis. Through a phronetic approach an evaluative framework to assess the crisis and shape the policy response that emphasizes the potential for people to be and do what they aspire in life as opposed to material resources or economic activity. The time when vaccine was under developed condition, most of the measures taken by individuals and government to slow down the spread of this contagious have been nonpharmaceutical interventions [152]. This led to two effective ways, one was to protect from the contamination and other was to decrease the pressure from the health systems. Even countries with high numbers of hospital beds and technologies, people suffered to have poor health services and it was overwhelmed during the peak of a pandemic, therefore, how to protect the public from the disease has been intensely researched (Fig. 6).

This uncertain crisis creates the socio-economic inequalities in a very harsh manner. Migrant workers were very much affected by the sudden lockdown. But that time it was needed as an urgent measure to control the spread of COVID-19. And the best example of implement the full lockdown country was India. Following India's method, other country follow shutdown their country partially but did not receive optimal results. The phronetic decisions by the Government of India gave good results and control over the disease in a large scale. Indian had already felt that it has poor healthcare system and during the shutdown period Government therefore has created awareness among people through the help of social media, news with the help of laws and improved a better health care system (COVID-care centers) in short time span and how to protect the lives and livelihoods of migrant workers. It is now to rest the mind to overcome from the current crisis. Government and policymakers should very deeply focus on reducing the economic inequalities and enhance the growth. So, it was the alarming time for government to monitor every situation and taking phronetic decision at every stage [31]. 
9.2 Future challenges and phronetic need during COVID-19

The whole society has very much affected or one can say after lockdown it has a pause under the current pandemic. The society had two categories of people in relation to COVID-19 i.e., with uncertainty and with certainty. People in an uncertain situation felt that there is no specific information till now on when situations will be stabilized [152]. On other aspect of certainty, people are experiencing worthy lessons through this global crisis and the life after this unprecedented situation will be changed and better and will also adopt a new normal and better life. According to Aristotelian phronesis, "it is during our darkest moments that we must focus to see the light”. Thus, society needs the phronesis for the betterment of new normal life and this is conceivably the right time to look ahead at projected improvements in the post-COVID world [153]. People are realising slowly that human values and practical wisdom are immensely necessary for nurturing the nature. They also realized the necessity of sustainable lifestyle for the strength and health of the planet earth.

So, in future more to save the planet, more environment-friendly paths will be adopted and explore new techniques such as: remote working to save fuel and control the pollution and online paper transactions, give more priority to maintain simple life style, use of artificial intelligence in different sectors etc. The sector where phronesis is strongly needed is to upgrade the Health care sector [155, 156]. Many frontline workers like medical and para medical staffs are in stress in the present times, but future demands for digital health technologies such as the use of contactless thermometers, improving patient care through boosting their will power, robotic monitoring of patients condition and delivering medicines etc. could solve the issues [155]. Similarly, creating more awareness among the public for maintaining social distancing and wearing masks and hand sanitization could be the new hygienic habit because public should learn how to live with COVID19. Increasing digital tools and methods such the use of telemedicine will convenient access to medical assistance. Such habits need to be practised in the educational institutions and similar hubs where gathering is normal [70, 156159]. Therefore, the education institute will create new infrastructure, need to cope of with technology in their teaching skills as to utilise new online different tools and apps to reduce the contamination. Virtual class rooms are only the system to take over the traditional teaching methods. So, the future phronetic need is to be digitally restructuring the education sector. Counselling and medical facilitation with telemetry can reduce anxiety and depression in such sectors to reduce distractions. It will save mental disruption of people under this or any future pandemic. So, development of social connectedness in every sector including medical and educational sectors is essential in a well-formed manner (Fig. 7).
Medical/social counselling for productive work, positive thought, critical thinking with patience to engage them in nurturing self and the environment could be the long term goals. Until a vaccine helps to build up immunity in the majority of the population, social distancing is only the measures to adopt by every individual. So, workfrom home, meeting through new digital tools and apps such as video conferencing will become the new work culture. Spending time with family and work from home culture may give breaks from work-pressure, nurture to make closer family-ties (Fig. 6).

The virulent virus gives a lesson to the current society. This is the high time to reflect on Aristotelian phronesis to explore the better life. And now people slowly work together in breaking the chain of SARS-CoV-2 infection, a better world is developing. The hard times are sure to pass, leaving behind the phronetic practicing of reflecting one self and find one's purpose to maintain compassion and caring for what genuinely matters in life, like the welfare of society through science (Fig. 8). By taking the help of phronesis the present world realised in three ways i.e., 1. People do not increase the risk factors, 2. It is not possible and against the human nature but current times need this measure a lot to isolate them for protecting others and 3. Follow all the government guidelines as a phronetic measures and always stay positive and productive and realized the need for precautions and are taking steps against future possibilities, to keep the coming generations safe.

\section{Summary and perspective}

COVID-19 infection has emerged as the greatest pandemic on this earth. It has already taken thousands of lives and millions of people have been facing erratic circumstances. It has imposed permanent damage on the economy and has radically changed the social life-style, occupations, education and business. Though the condition is getting recovered gradually, it has created a long-lasting impact on each and every sector of life. Nearly the entire world has to undergo a phase of lockdown for a long period of time with a different level of stringency to fight against COVID-19. Each and every nation is now trying hard to get back to the normal phase of life gradually. The educational institutes are reopening with restrictions. Due to the shutdown of industries and all sorts of transports; there is a drastic change in the climate. The level $\mathrm{NO}_{2}$ and $\mathrm{CO}_{2}$ emissions got significantly reduced in many metropolitan cities globally [160]. This has made wildlife move with full liberty. The diligent and collaborative efforts of a large number of scientists across the world have been able to produce safe and effective vaccines against this deadly virus. It is anticipated that the pandemic situation will come under control very soon. We believe that this review article will give a holistic and updated status of epidemiology, therapeutic interventions, vaccine development for COVID-19, 


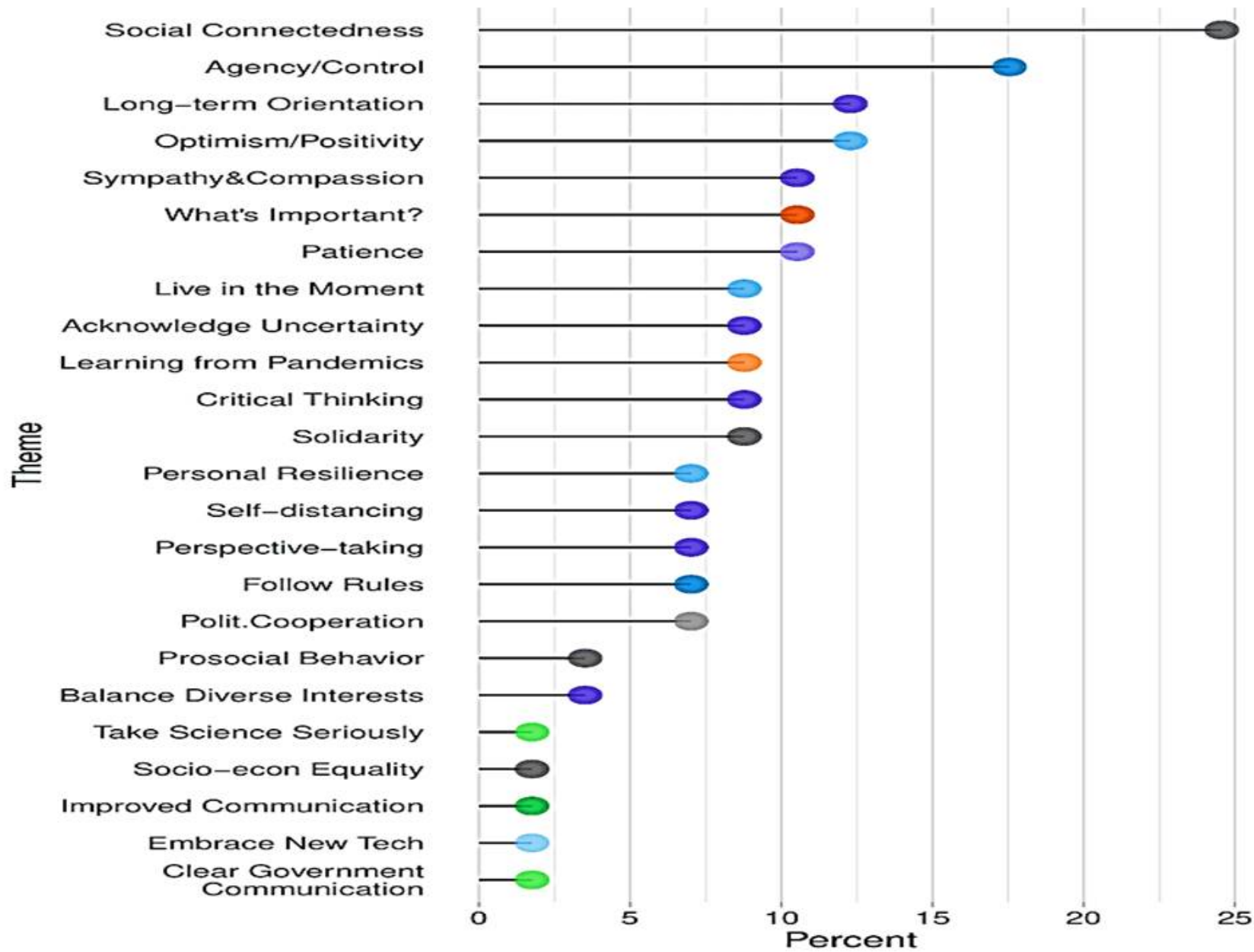

Fig. 7. Future challenges during any pandemic situation through which one can enhance the mental peace (Source. Google images under creative common attribution license).

and various aspects of public health, economy, education, social life, and natural environment which are significantly affected by this pandemic. Finally, we have discussed the phronetic attitude that everyone should develop to overcome the current crisis for the betterment of our future life.

\section{Author contributions}

KD, BP, MSP, and SKS have concetulize the review, drafted and edited the review. FP, SGP, AS, PKV have drafted and edited the review.

\section{Ethics approval and consent to participate}

Not applicable.

\section{Acknowledgment}

The authors thank the Prof. PK Agrawal, honorable Vice chancellor of OUAT, Prof. Sabita Acharya, honorable Vice chancellor of Utkal University and the Director of IIIT, Allahabad for their encouragements to accomplish this work.

\section{Funding}

Schemes (number No. ECR/2016/001984 by SERB, DST, Govt. of India and 1188/ST, Bhubaneswar, dated 01.03.17, ST- (Bio)-02/2017 and DST, Govt. of Odisha, India) to BRP are acknowledged. Funding to KD (36 Seed/2019/Philosophy-1, letter number 941/69/OSHEC/2019 dt 22.11.19) from the Department of Higher Education, Govt. of Odisha under OURIIP scheme is dully acknowledged. Acknowledge to IIIT Allahabad for providing research facility.

\section{Conflict of interest}

The authors declare that there is no conflict of interest. 


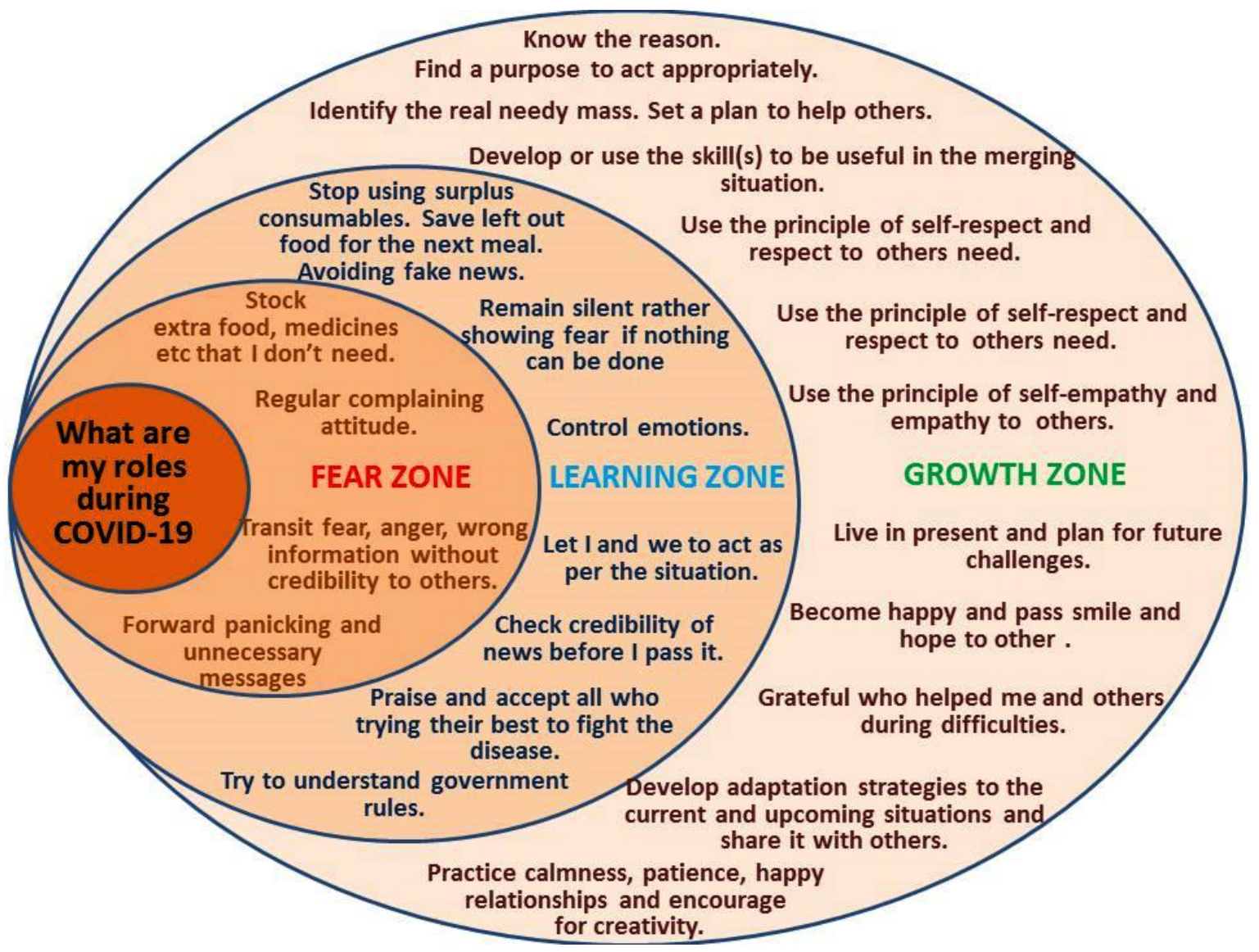

Fig. 8. Use the phronesis one can monitoring himself/herself and take a good decision in the difficult times and also stay positive and productive (Source. Google images under creative common attribution license).

\section{References}

[1] Paital B, Das K, Parida SK. Inter nation social lockdown versus medical care against COVID-19, a mild environmental insight with special reference to India. Science of the Total Environment. 2020; 728: 138914.

[2] Paital B, Das K, Behera T. Social lockdown and ecological intervention for the prevention of the community spread of COVID19. Cancer Research, Statistics, and Treatment. 2020; 3: 667669.

[3] Lu R, Zhao X, Li J, Niu P, Yang B, Wu H, et al. Genomic characterisation and epidemiology of 2019 novel coronavirus: implications for virus origins and receptor binding. Lancet. 2020; 395: 565-574.

[4] Zhou P, Yang XL, Wang XG, Hu B, Zhang L, Zhang W, et al. A pneumonia outbreak associated with a new coronavirus of probable bat origin. Nature. 2020; 579: 270-273.

[5] Lam TT, Jia N, Zhang YW, Shum MH, Jiang JF, Zhu HC, et al. Identifying SARS-CoV-2-related coronaviruses in Malayan pangolins. Nature. 2020; 583: 282-285.

[6] Chan JF, Yuan S, Kok K, To KK, Chu H, Yang J, et al. A familial cluster of pneumonia associated with the 2019 novel coronavirus indicating person-to-person transmission: a study of a family cluster. Lancet. 2020; 395: 514-523.

[7] Bradney L, Wijesekara H, Palansooriya KN, Obadamudalige N, Bolan NS, Ok YS, et al. Particulate plastics as a vector for toxic trace-element uptake by aquatic and terrestrial organisms and human health risk. Environment International. 2019; 131: 104937

[8] Urban RC, Nakada LYK. COVID-19 pandemic: solid waste and environmental impacts in Brazil. Science of the Total Environ- ment. 2021; 755: 142471.

[9] Holshue ML, DeBolt C, Lindquist S, Lofy KH, Wiesman J, Bruce H, et al. First case of 2019 novel coronavirus in the United States. New England Journal of Medicine. 2020; 382: 929-936.

[10] Zhu H, Wang L, Fang C, Peng S, Zhang L, Chang G, et al. Clinical analysis of 10 neonates born to mothers with 2019-nCoV pneumonia. Translational Pediatrics. 2020; 9: 51-60.

[11] Paital B, Agrawal PK. Air pollution by NO2 and PM2.5 explains COVID-19 infection severity by overexpression of angiotensinconverting enzyme 2 in respiratory cells: a review. Environmental Chemistry Letters. 2021; 19: 25-42.

[12] Liu T, Hu J, Xiao J, He G, Kang M, Rong Z, et al. Timevarying transmission dynamics of novel coronavirus pneumonia in China. bioRxiv. 2020. (in press)

[13] Shivalkar S, Verma A, Singh A, Singh V, Shiva Priya PM, Paital B, Das D, Varadwaj PK, Samanta SK. Outbreak of COVID-19: a detailed overview and its consequences. Heat Shock Proteins. 2021. (in press)

[14] Li F. Structure, function, and evolution of coronavirus spike proteins. Annual Review of Virology. 2016; 3: 237-261.

[15] Wu A, Peng Y, Huang B, Ding X, Wang X, Niu P, et al. Genome composition and divergence of the novel coronavirus (2019nCoV) originating in China. Cell Host \& Microbe. 2020; 27: 325-328.

[16] Wei WE, Li Z, Chiew CJ, Yong SE, Toh MP, Lee VJ. Presymptomatic transmission of SARS-CoV-2- Singapore, January 23March 16, 2020. Morbidity and Mortality Weekly Report. 2020; 69: $411-415$

[17] Hoffmann M, Kleine-Weber H, Schroeder S, Krüger N, Herrler $\mathrm{T}$, Erichsen S, et al. SARS-CoV-2 cell entry depends on ACE-2 
and TMPRSS2 and is blocked by a clinically proven protease inhibitor. Cell. 2020; 181: 271-280.e8.

[18] Mu J, Xu J, Zhang L, Shu T, Wu D, Huang M, et al. SARS$\mathrm{CoV}$-2-encoded nucleocapsid protein acts as a viral suppressor of RNA interference in cells. Science China Life Sciences. 2020; 63: 1-4.

[19] Angelini MM, Akhlaghpour M, Neuman BW, Buchmeier MJ. Severe acute respiratory syndrome coronavirus nonstructural proteins 3,4 , and 6 induce double-membrane vesicles. MBio. 2013; 4: e00524-13.

[20] Kirchdoerfer RN, Ward AB. Structure of the SARS-CoV nsp12 polymerase bound to nsp7 and nsp8 co-factors. Nature Communications. 2019; 10: 2342.

[21] Snijder EJ, Decroly E, Ziebuhr J. The nonstructural proteins directing coronavirus RNA synthesis and processing. Advances in Virus Research. 2016; 96: 59-126.

[22] He Y, Zhou Y, Liu S, Kou Z, Li W, Farzan M, et al. Receptorbinding domain of SARS-CoV spike protein induces highly potent neutralizing antibodies: implication for developing subunit vaccine. Biochemical and Biophysical Research Communications. 2004; 324: 773-781.

[23] Lotfi M, Hamblin MR, Rezaei N. COVID-19: transmission, prevention, and potential therapeutic opportunities. Clinica Chimica Acta. 2020; 508: 254-266.

[24] Peeri NC, Shrestha N, Rahman MS, Zaki R, Tan Z, Bibi S, et al. The SARS, MERS and novel coronavirus (COVID-19) epidemics, the newest and biggest global health threats: what lessons have we learned? International Journal of Epidemiology. 2020; 49: 717-726.

[25] Shi J, Wen Z, Zhong G, Yang H, Wang C, Huang B, et al. Susceptibility of ferrets, cats, dogs, and other domesticated animals to SARS-coronavirus 2. Science. 2020; 368: 1016-1020.

[26] The STRAITSTIMES. Second dog in Hong Kong tests positive for coronavirus 2020 MAR 20. 2020. Available at: https://www.straitstimes.com/asia/east-asia/second-dog-in-hon g-kong-tests-positive-for-coronavirus (Accessed: 26 February 2020).

[27] Ahn D, Shin H, Kim M, Lee S, Kim H, Myoung J, et al. Current status of epidemiology, diagnosis, therapeutics, and vaccines for novel coronavirus disease 2019 (COVID-19). Journal of Microbiology and Biotechnology. 2020; 30: 313-324.

[28] van Doremalen N, Bushmaker T, Morris DH, Holbrook MG, Gamble A, Williamson BN, et al. Aerosol and surface stability of SARS-CoV-2 as compared with SARS-CoV-1. The New England Journal of Medicine. 2020; 382: 1564-1567.

[29] Das K, Paital B. First week of social lockdown versus medical care against COVID-19 with special reference to India. Current Trends in Biotechnology and Pharmacy. 2020; 14: 196-216.

[30] Das K, Behera TR, Paital B. Heat Shock Protein, Corona Virus COVID-19. In Kaur P, Asea A. (ed.) Outbreak challenges in Indian migrant pregnant and lactating mothers: learnt lesson demands hierarchical strategy for such future situation. USA: Springer. 2021.

[31] Mousazadeh M, Paital B, Naghdali Z, Mortezania Z, Hashemi M, Karamati Niaragh E, et al. Positive environmental effects of the coronavirus 2020 episode: a review. Environment, Development And Sustainability. 2021. (in press)

[32] Paital B, Agrawal PK. COVID-19 in the Environment. In Rawtani D, Hussain CM, Khatri N. (ed.) Role of environmental factors in transmission of COVID-19. USA: Elsevier. 2021.

[33] Das K, Behera TR, Paital B. COVID-19 in the Environment. In Rawtani D, Hussain CM, Khatri N. (ed.) Socio-economic impact of COVID-19. Elsevier: USA. 2021.

[34] Santarpia JL, Rivera DN, Herrera V, Morwitzer MJ, Creager H, Santarpia GW, et al. Transmission potential of SARS-CoV-2 in viral shedding observed at the university of Nebraska medical center. medRxiv. 2020. (in press)

[35] Dao TL, Hoang VT, Gautret P. Recurrence of SARS-CoV-2 viral RNA in recovered COVID-19 patients: a narrative review. Eur
J Clin Microbiol Infect Dis. 2021: 40(1): 13-25.

[36] Tang JW, Li Y, Eames I, Chan PKS, Ridgway GL. Factors involved in the aerosol transmission of infection and control of ventilation in healthcare premises. Journal of Hospital Infection. 2006; 64: 100-114.

[37] MacLoughlin R, Telfer C, Clark A, Fink J. Aerosol: a novel vehicle for pharmacotherapy in neonates. Current Pharmaceutical Design. 2017; 23: 5928-5934.

[38] Anderson EL, Turnham P, Griffin JR, Clarke CC. Consideration of the aerosol transmission for COVID 19 and public health. Risk Analysis. 2020; 40: 902-907.

[39] Zou L, Ruan F, Huang M, Liang L, Huang H, Hong Z, et al. SARS-CoV-2 viral load in upper respiratory specimens of infected patients. New England Journal of Medicine. 2020; 382: 1177-1179.

[40] Wilson NM, Norton A, Young FP, Collins DW. Airborne transmission of severe acute respiratory syndrome coronavirus 2 to healthcare workers: a narrative review. Anaesthesia. 2020; 75 1086-1095.

[41] Klompas M, Baker MA, Rhee C. Airborne Transmission of SARS-CoV-2: Theoretical Considerations and Available Evidence. The Journal of the American Medical Association. 2020; 324: 441.

[42] Tang S, Mao Y, Jones RM, Tan Q, Ji JS, Li N, et al. Aerosol transmission of SARS-CoV-2? Evidence, prevention and control. Environment International. 2020; 144: 106039.

[43] In 't Veen J, de Hond M, Boerstra AC. Viral transmission in COVID-19: the role of the aerosol. Nederlands Tijdschrift voor Geneeskunde. 2020; 164: D5399.

[44] Ueki H, Furusawa Y, Iwatsuki-Horimoto K, Imai M, Kabata $\mathrm{H}$, Nishimura $\mathrm{H}$, et al. Effectiveness of face masks in preventing airborne transmission of SARS-CoV-2. mSphere. 2020; 5 : e00637-20.

[45] Sharma S, Zhang M, Anshika, Gao J, Zhang H, Kota SH. Effect of restricted emissions during COVID-19 on air quality in India. Science of the Total Environment. 2020; 728: 138878.

[46] Bradney L, Wijesekara H, Palansooriya KN, Obadamudalige N, Bolan NS, Ok YS, et al. Particulate plastics as a vector for toxic trace-element uptake by aquatic and terrestrial organisms and human health risk. Environment International. 2019; 131: 104937.

[47] WHO. WHO Coronavirus Disease (COVID-19) Dashboard. 2021. Available at: https://covid19.who.int/ (Accessed: 3 March 2021).

[48] Liu Y, Kuo R, Shih S. COVID-19: the first documented coronavirus pandemic in history. Biomedical Journal. 2020; 43: 328333.

[49] Tositti L, Brattich E, Parmeggiani S, Bolelli L, Ferri E, Girotti S. Airborne particulate matter biotoxicity estimated by chemometric analysis on bacterial luminescence data. Science of the Total Environment. 2018; 640-641: 1512-1520.

[50] Gao Z, Xu Y, Sun C, Wang X, Guo Y, Qiu S, et al. A systematic review of asymptomatic infections with COVID-19. Journal of Microbiology, Immunology and Infection. 2021; 54: 12-16.

[51] Carraturo F, Del Giudice C, Morelli M, Cerullo V, Libralato $\mathrm{G}$, Galdiero E, et al. Persistence of SARS-CoV-2 in the environment and COVID-19 transmission risk from environmental matrices and surfaces. Environmental Pollution. 2020; 265: 115010.

[52] Al Huraimel K, Alhosani M, Kunhabdulla S, Stietiya MH SARS-CoV-2 in the environment: modes of transmission, early detection and potential role of pollutions. Science of the Total Environment. 2020; 744: 140946.

[53] Bai Y, Yao L, Wei T, Tian F, Jin D, Chen L, et al. Presumed asymptomatic carrier transmission of COVID-19. The Journal of the American Medical Association. 2020; 323: 1406-1407.

[54] Nicastri E, D’Abramo A, Faggioni G, De Santis R, Mariano A, Lepore L, et al. Coronavirus disease (COVID-19) in a paucisymptomatic patient: epidemiological and clinical challenge 
in settings with limited community transmission, Italy, February 2020. Eurosurveillance. 2020; 25: 2000230.

[55] Rothe C, Schunk M, Sothmann P, Bretzel G, Froeschl G, Wallrauch C, et al. Transmission of 2019-nCoV infection from an asymptomatic contact in Germany. New England Journal of Medicine. 2020; 382: 970-971.

[56] WHO. Coronavirus disease (COVID-19) pandemic. 2021. Available at: https://www.who.int/emergencies/diseases/novel -coronavirus-2019 (Accessed: 28 February 2021).

[57] Medema G, Heijnen L, Elsinga G, Italiaander R, Brouwer A. Presence of SARS-Coronavirus-2 in Sewage. medRxiv. 2020. (in press)

[58] Wurtzer S, Marechal V, Mouchel JM, Moulin L. Time course quantitative detection of SARS-CoV-2 in Parisian wastewaters correlates with COVID-19 confirmed cases. medRxiv. 2020. (in press)

[59] Ahmed W, Angel N, Edson J, Bibby K, Bivins A, O’Brien JW, et al. First confirmed detection of SARS-CoV-2 in untreated wastewater in Australia: a proof of concept for the wastewater surveillance of COVID-19 in the community. Science of the Total Environment. 2020; 728: 138764.

[60] Rowan NJ, Laffey JG. Unlocking the surge in demand for personal and protective equipment (PPE) and improvised face coverings arising from coronavirus disease (COVID-19) pandemic - implications for efficacy, re-use and sustainable waste management. Science of the Total Environment. 2021; 752: 142259

[61] La Rosa G, Iaconelli M, Mancini P, Bonanno Ferraro G, Veneri C, Bonadonna L, et al. First detection of SARS-CoV-2 in untreated wastewaters in Italy. Science of the Total Environment. 2020; 736: 139652.

[62] Pirouz B, Golmohammadi A, Masouleh HS, Violini G, Pirouz B. Relationship between average daily temperature and average $\mathrm{cu}-$ mulative daily rate of confirmed cases of COVID-19. medRxiv. 2020. (in press)

[63] Sajadi MM, Habibzadeh P, Vintzileos A, Shokouhi S, MirallesWilhelm F, Amoroso A. Temperature, humidity, and latitude analysis to estimate potential spread and seasonality of coronavirus disease 2019 (COVID-19). JAMA Netw Open. 2020; 3: e2011834.

[64] European Centre for Disease Prevention and Control. COVID19 situation update worldwide, as of week 10, updated 18 March 2021. 2021. Available at: https://www.ecdc.europa.eu/en/geog raphical-distribution-2019-ncov-cases (Accessed: 26 February 2020).

[65] Filippini T, Hatch EE, Rothman KJ, Heck JE, Park AS, Crippa A, et al. Association between outdoor air pollution and childhood leukemia: a systematic review and dose-response meta-analysis. Environmental Health Perspectives. 2019; 127: 046002.

[66] Krauskopf J, van Veldhoven K, Chadeau-Hyam M, Vermeulen $\mathrm{R}$, Carrasco-Turigas G, Nieuwenhuijsen $\mathrm{M}$, et al. Short-term exposure to traffic-related air pollution reveals a compoundspecific circulating miRNA profile indicating multiple disease risks. Environment International. 2019; 128: 193-200.

[67] Hassoun D, Moui A, Colas L, Blanc FX, Magnan A. Actualités physiopathologiques et thérapeutiques dans l'asthme sévère. La Revue De MéDecine Interne. 2019; 40: 508-516. (In French)

[68] Ministry of Health and Family Welfare Government of India. Government of India, 2020. 2020. Accessed at: https://www. mohfw.gov.in/ (Accessed: 28 February 2021).

[69] Sharma A, Balyan P. Air pollution and COVID-19: is the connect worth its weight? Indian Journal of Public Health. 2020; 64: 132.

[70] Ogen Y. Assessing nitrogen dioxide ( $\mathrm{NO}(2))$ levels as a contributing factor to coronavirus (COVID-19) fatality. Science of the Total Environment. 2020; 726: 138605.

[71] Gendrot M, Andreani J, Boxberger M, Jardot P, Fonta I, Le Bideau M, et al. Antimalarial drugs inhibit the replication of SARS-CoV-2: an in vitro evaluation. Travel Medicine and In- fectious Disease. 2020; 37: 101873.

[72] Chugh H, Awasthi A, Agarwal Y, Gaur RK, Dhawan G, Chandra R. A comprehensive review on potential therapeutics interventions for COVID-19. European Journal of Pharmacology. 2021; 890: 173741.

[73] Glinsky GV. Tripartite combination of candidate pandemic mitigation agents: vitamin $\mathrm{D}$, quercetin, and estradiol manifest properties of medicinal agents for targeted mitigation of the COVID19 pandemic defined by genomics-guided tracing of SARSCoV-2 targets in human cells. Biomedicines. 2020; 8: 129.

[74] COVID-19 Treatment Guidelines Panel. 2020. Coronavirus disease 2019 (COVID-19) treatment guidelines. National Institutes of Health. 2021. Available at: https://www.covid19treatmentgu idelines.nih.gov/ (Accessed: 24 February 2021).

[75] U. S. Dood \& Drug. FDA approves first treatment for covid19. 2020. Available at: www.fda.gov/news-events/press-annou ncements/fda-approves-first-treatment-covid-19 (Accessed: 22 October 2020).

[76] Beigel JH, Tomashek KM, Dodd LE, Mehta AK, Zingman BS, Kalil AC, et al. Remdesivir for the treatment of Covid-19final report. The New England Journal of Medicine. 2020; 383: 1813-1826.

[77] U. S. Dood \& Drug. Coronavirus (COVID-19) Update: FDA Authorizes Monoclonal Antibodies for Treatment of COVID19. 2020. Available at: www.fda.gov/news-events/press-annou ncements/coronavirus-covid-19-update-fda-authorizes-monoc lonal-antibodies-treatment-covid-19 (Accessed: 21 November 2020).

[78] Arshad S, Kilgore P, Chaudhry ZS, Jacobsen G, Wang $\mathrm{DD}$, Huitsing $\mathrm{K}$, et al. Treatment with hydroxychloroquine, azithromycin, and combination in patients hospitalized with COVID-19. International Journal Of Infectious Diseases. 2020; 97: 396-403.

[79] Chandwani A, Shuter J. Lopinavir/ritonavir in the treatment of HIV-1 infection: a review. Therapeutics and Clinical Risk Management. 2008; 4: 1023-1033.

[80] Zumla A, Chan JFW, Azhar EI, Hui DSC, Yuen K. Coronaviruses-drug discovery and therapeutic options. Nature Reviews. Drug Discovery. 2016; 15: 327-347.

[81] Ye XT, Luo YL, Xia SC, Sun QF, Ding JG, Zhou Y, et al. Clinical efficacy of lopinavir/ritonavir in the treatment of Coronavirus disease 2019. European Review for Medical and Pharmacological Sciences. 2020; 24: 3390-3396.

[82] Bowale A, Abayomi A, Idris J, Omilabu S, Abdus-Salam I, Adebayo B, et al. Clinical presentation, case management and outcomes for the first 32 COVID-19 patients in Nigeria. The Pan African Medical Journal. 2020; 35: 24.

[83] Cao B, Wang Y, Wen D, Liu W, Wang J, Fan G, et al. A trial of lopinavir-ritonavir in adults hospitalized with severe Covid-19. New England Journal of Medicine. 2020; 382: 1787-1799.

[84] Mahdi M, Mótyán JA, Szojka ZI, Golda M, Miczi M, Tőzsér J. Analysis of the efficacy of HIV protease inhibitors against SARS-CoV-2's main protease. Virology Journal. 2020; 17: 190.

[85] World Health Organization. WHO discontinues hydroxychloroquine and lopinavir/ritonavir treatment arms for Covid-19. 2020. Available at: Https://Www.Who.Int/News-Room/Detail 104-07-2020-Who-Discontinues-Hydroxychloroquine-and-L opinavir-Ritonavir-Treatment-Arms-For-Covid-19 (Accessed: 24 Feburary 2021).

[86] McGregor SK. Energetics based modeling of hydroxychloroquine and azithromycin binding to the SARS-CoV-2 spike (S)Protein-ACE-2 complex. ChemRxiv. 2020. (in press)

[87] Golden EB, Cho H, Hofman FM, Louie SG, Schönthal AH, Chen TC. Quinoline-based antimalarial drugs: a novel class of autophagy inhibitors. Neurosurgical Focus. 2015; 38: E12.

[88] Boulware DR, Pullen MF, Bangdiwala AS, Pastick KA, Lofgren $\mathrm{SM}$, Okafor EC, et al. A randomized trial of hydroxychloroquine as postexposure prophylaxis for Covid-19. New England Journal of Medicine. 2020; 383: 517-525. 
[89] Magagnoli J, Narendran S, Pereira F, Cummings TH, Hardin JW, Sutton SS, et al. Outcomes of hydroxychloroquine usage in United States veterans hospitalized with COVID-19. Med. 2020; 1: 114-127.e3.

[90] Ferner R, Aronson J. Chloroquine and hydroxychloroquine in Covid-19. British Medical Journal. 2020; 369: M1432.

[91] Nga L, Phuong L, Anh P. Hanoi Man Od's On Rumored Malaria Drug Cure For Covid-19. 2020. Available at: Https://E.Vnexpress.Net/News/News/Hanoi-Man-Od-S-O n-Rumored-Malaria-Drug-Cure-For-Covid-19-4073488 (Accessed: 26 February 2021)

[92] NIH. NIH halts clinical trial of hydroxychloroquine. 2020. Available at: Https://Www.Nhlbi.Nih.Gov/News/2020/Nih-Hal ts-Clinical-Trial-Hydroxychloroquine (Accessed: 15 December 2020).

[93] Chen C, Zhang Y, Huang J, Yin P, Cheng Z, Wu J, et al. Favipiravir versus arbidol for COVID-19: a randomized clinical trial. Medrxiv. 2020. (in press)

[94] Ivashchenko AA, Dmitriev KA, Vostokova NV, Azarova VN, Blinow AA, Egorova AN, et al. AVIFAVIR for treatment of patients with moderate COVID-19: interim results of a phase II/III multicenter randomized clinical trial. Clinical Infectious Diseases. 2020. (in press)

[95] Cai Q, Yang M, Liu D, Chen J, Shu D, Xia J, et al. Experimental treatment with favipiravir for COVID-19: an open-label control study. Engineering. 2020; 6: 1192-1198.

[96] Sheahan TP, Sims AC, Leist SR, Schäfer A, Won J, Brown AJ, et al. Comparative therapeutic efficacy of remdesivir and combination lopinavir, ritonavir, and interferon beta against MERS-CoV. Nature Communications. 2020; 11: 222.

[97] Uzunova K, Filipova E, Pavlova V, Vekov T. Insights into anti-viral mechanisms of remdesivir, lopinavir/ritonavir, and quine/hydroxychloroquine affecting the new SARS-CoV-2. Biomed Pharmacother. 2020; 131: 110668

[98] Siemieniuk R, Rochwerg B, Agoritsas T, Lamontagne F, Leo YS, Macdonald $\mathrm{H}$, et al. A living WHO guideline on drugs for covid-19. British Medical Journal. 2020; 370: m3379.

[99] Beigel JH, Tomashek KM, Le D, et al. Remdesivir for the treatment of Covid-19—preliminary report. New England Journal of Medicine. 2020; 383: 992-994.

[100] US Food and Drug Administration. Emergency use authorization (EUA) for emergency use of remdesivir for the treatment of hospitalized coronavirus disease (Covid-19) patients. 2020. Available at: Https://Www.Fda.Gov/Media/137564/Download (Accessed: 15 December 2020).

[101] Charan J, Kaur RJ, Bhardwaj P, Haque M, Sharma P, Misra $\mathrm{S}$, et al. Rapid review of suspected adverse drug events due to remdesivir in the who database; findings and implications. Expert Review of Clinical Pharmacology. 2021; 14: 95-103.

[102] RAPS. COVID-19 vaccine tracker. 2021. Available at: https://www.raps.org/news-and-articles/news-articles/2020/3/ covid-19-vaccine-tracker (Accessed: 21 February 2021).

[103] Russell RL, Pelka P, Mark BL. Frontrunners in the race to develop a SARS-CoV-2 vaccine. Canadian Journal of Microbiology. 2021; 67: 189-212.

[104] Precision Vaccine. EpiVacCorona Vaccine. 2021. Available at: https://www.precisionvaccinations.com/vaccines/epivaccor ona-vaccine (Accessed: 23 February 2021).

[105] Precision Vaccine. Covaxin COVID-19 Vaccine. 2021. Available at: https://www.precisionvaccinations.com/vaccines/covax in-covid-19-vaccine (Accessed: 3 February 2021).

[106] Xia S, Zhang Y, Wang Y, Wang H, Yang Y, Gao GF, et al. Safety and immunogenicity of an inactivated SARS-CoV2 vaccine, BBIBP-CorV: a randomised, double-blind, placebocontrolled, phase 1/2 trial. Lancet Infectious Diseases. 2021; 21: 39-51.

[107] Zhang Y, Zeng G, Pan H, Li C, Hu Y, Chu K, et al. Safety, tolerability, and immunogenicity of an inactivated SARS-CoV2 vaccine in healthy adults aged $18-59$ years: a randomised, double-blind, placebo-controlled, phase 1/2 clinical trial. Lancet Infectious Diseases. 2021; 21: 181-192.

[108] Precision Vaccine. Convidicea Vaccine. 2021. Available at: https://www.precisionvaccinations.com/vaccines/convidice a-ad5-ncov-vaccine (Accessed: 21 February 2021).

[109] Oliver SE. COVID-19 vaccines: Work Group interpretation. 2020.

[110] Voysey M, Clemens SAC, Madhi SA, Weckx LY, Folegatti PM, Aley PK, et al. Safety and efficacy of the ChAdOx1 nCoV-19 vaccine (AZD1222) against SARS-CoV-2: an interim analysis of four randomised controlled trials in Brazil, South Africa, and the UK. Lancet. 2021; 397: 99-111.

[111] Precision Vaccine. INO-4800 COVID-19 Vaccine. 2021. Available at: https://www.precisionvaccinations.com/vaccines/ino -4800-dna-coronavirus-vaccine (Accessed: 21 February 2021).

[112] Medline Plus. Bacillus Calmette-Guerin (BCG) Vaccine. 2021. Available at: https://medlineplus.gov/druginfo/meds/a682809. html (Accessed: 19 February 2021).

[113] Precision Vaccine. NVX-CoV2373 COVID-19 Vaccine. 2021. Available at: https://www.precisionvaccinations.com/vaccines /nvx-cov2373-SARS-CoV-2-vaccine (Accessed: 16 February 2021).

[114] Yadav PD, Kumar S, Agarwal K, Jain M, Patil DR, Maithal K, et al. Assessment of immunogenicity and protective efficacy of ZyCoV-D DNA vaccine candidates in Rhesus macaques against SARS-CoV-2 infection. bioRxiv. 2021. (in press)

[115] Precision Vaccine. CVnCoV Vaccine. 2021. Available at: https: //www.precisionvaccinations.com/vaccines/cvncov-vaccine (Accessed: 15 February 2021).

[116] GSK. Vir Biotechnology and GSK announce global expansion to Phase 3 of COMET-ICE study evaluating VIR-7831 for the treatment of COVID-19. 2020. Available at: https: //www.gsk.com/en-gb/media/press-releases/vir-biotechnology -and-gsk-announce-global-expansion-to-phase-3-of-comet-i ce-study-evaluating-vir-7831-for-the-treatment-of-covid-19/ (Accessed: 23 February 2021).

[117] Wibawa T. COVID-19 vaccine research and development: ethical issues. Tropical Medicine \& International Health. 2021; 26 $14-19$.

[118] NIH. A Study to Evaluate the Safety, Tolerability, and Immunogenicity of UB-612 COVID-19 Vaccine. 2020. Available at: https://clinicaltrials.gov/ct2/show/NCT04545749 (Accessed: 13 February 2021).

[119] BMJ. Covid-19: Russian vaccine efficacy is $91.6 \%$, show phase III trial results. 2021. Available at: https://www.bmj.co m/content/372/bmj.n309/rr-0 (Accessed: 23 February 2021).

[120] Pfizer. Pfizer and biontech to supply Canada with their BNT162 mRNA-based vaccine candidate. 2021; Available at: https://www.pfizer.com/news/press-release/press-release-detai 1/pfizer-and-biontech-supply-canada-their-bnt162-mrna-based (Accessed: 26 February 2021).

[121] NIH. Safety and Immunogenicity Study of AdCLD-CoV19: A COVID-19 preventive vaccine in healthy volunteers. 2020. Available at: https://clinicaltrials.gov/ct2/show/NCT04666012 (Accessed: 15 February 2021).

[122] NIH. A clinical trial to assess the safety and immunogenicity of nanocovax in heathy volunteers. 2020. Available at: https://clin icaltrials.gov/ct2/show/NCT04683484 (Accessed: 24 February 2021).

[123] Institute of Biotechnology, Academy of Military Medical Sciences, PLA of China. 2021. Available at: https://clinicaltrials.g ov/ct2/show/NCT04341389 (Accessed: 12 February 2021).

[124] NIH. Evaluate the Safety, Immunogenicity and Potential Efficacy of an rVSV-SARS-CoV-2-S Vaccine. 2020. Available at: ht tps://clinicaltrials.gov/ct2/show/NCT04608305 (Accessed: 15 February 2021)

[125] National Health Commission of the PRC. COVID-19 vaccine candidate produced from insect cells to enter human trials 2020. Available at: http://en.nhc.gov.cn/2020-08/26/c_81483.ht 
m (Accessed: 22 February 2021).

[126] Precision Vaccine. Soberana 02 COVID-19 Vaccine. 2021. Available at: https://www.precisionvaccinations.com/vaccines /soberana-02-covid-19-vaccine (Accessed: 26 February 2021).

[127] Valneva. COVID-19-VLA2001. 2021. Available at: http s://valneva.com/research-development/covid-19-vla2001/ (Accessed: 16 February 2021)

[128] Thanh Le T, Andreadakis Z, Kumar A, Gómez Román R, Tollefsen S, Saville M, et al. The COVID-19 vaccine development landscape. Nature Reviews Drug Discovery. 2020; 19: 305-306.

[129] WHO. Coronavirus. 2021. Available at: https://www.who.int/ health-topics/coronavirus (Accessed: 16 February 2021).

[130] Xiang M, Zhang Z, Kuwahara K. Impact of COVID-19 pandemic on children and adolescents' lifestyle behavior larger than expected. Progress in Cardiovascular Diseases. 2020; 63: 531532.

[131] Hall G, Laddu DR, Phillips SA, Lavie CJ, Arena R. A tale of two pandemics: how will COVID-19 and global trends in physical inactivity and sedentary behavior affect one another? Progress in Cardiovascular Diseases. 2020; 64: 108-110.

[132] Haleem A, Javaid M, Vaishya R. Effects of COVID-19 pandemic in daily life. Current Medicine Research and Practice. 2020; 10: 78-79.

[133] McKibbin WJ, Fernando R. The global macroeconomic impacts of COVID-19: seven scenarios. 2020. Available at: https://www.brookings.edu/wp-content/uploads/2020/ 03/20200302_COVID19.pdf. Retrieved on 28 July 2020 (Accessed: 23 February 2021).

[134] OECD. 2021. Policy Responses to Coronavirus (COVID-19) Youth and COVID-19: response, recovery and resilience. Available at: https://www.oecd.org/coronavirus/policy-respons es/youth-and-covid-19-response-recovery-and-resilience-c40e 61c6/ (Accessed: 11 June 2022).

[135] Das K, Behera RL, Paital B. Global impacts of COVID-19 on socio-economic, education and ethico-religious factors. In: Heat shock protein corona virus. Asea AAA, Punit K. (Eds.). Springer-Nature. 2020. (in press)

[136] Wang Y, Tian H, Zhang L, Zhang M, Guo D, Wu W, et al. Reduction of secondary transmission of SARS-CoV-2 in households by face mask use, disinfection and social distancing: a cohort study in Beijing, China. BMJ Global Health. 2020; 5: e002794.

[137] Bavel JJV, Baicker K, Boggio PS, Capraro V, Cichocka A, Cikara $\mathrm{M}$, et al. Using social and behavioural science to support COVID-19 pandemic response. Nature Human Behaviour. 2020; 4: 460-471.

[138] Wallace JD. Moral Relevance and Moral Conflict. N.Y: Cornel, Ithaca. 1988

[139] Abrams D, Wetherell M, Cochrane S, Hogg MA, Turner JC. Knowing what to think by knowing who you are: selfcategorization and the nature of norm formation, conformity and group polarization. British Journal of Social Psychology. 1990; 29: 97-119.

[140] Schultz PW, Nolan JM, Cialdini RB, Goldstein NJ, Griskevicius V. The constructive, destructive, and reconstructive power of social norms. Psychological Science. 2007; 18: 429-434.

[141] Noel J. On the varieties of phronesis. Educational Philosophy and Theory. 1999; 31: 273-289.

[142] Taylor CCW. The Oxford companion to philosophy. In Hondrich T. (ed.) Phronesis. Oxford: Oxford University Press. 2005.

[143] Schwartz B, Sharpe KE. Practical wisdom: aristotle meets positive psychology. Journal of Happiness Studies. 2006; 7: 377395.

[144] Kinsella EA. Practitioner Reflection and Judgement as Phronesis. In Kinsella EA, Pitman A. (ed.) Phronesis as Profesional knowledge: Practical Wisdom in the Professions. Rotterdam: Sense Publishers. 2012

[145] Aristotle. TheNicomachean Ethics, (trans.) D.P. Chase. London \& Tornto: The Temple Press Letchworth. 1911.

[146] Schwartz Barry, Sharpe Kenneth E. Practical wisdom. New York: Riverhead books. 2010.

[147] Flyvbjerg B. Making social science matter. Cambridge: Cambridge University Press. 2001

[148] Flyvbjerg B, Landman T, Schram S. Real social science: applied phronesis. Cambridge: Cambridge University Press. 2012.

[149] Brooks SK, Webster RK, Smith LE, Woodland L, Wessely S, Greenberg N, et al. The psychological impact of quarantine and how to reduce it: rapid review of the evidence. The Lancet. 2020 395: 912-920.

[150] Aristotle, Irwin T. Nicomachean Ethics, Second Edition. 1392. London: Oxford Press. 1999.

[151] Basol M, Roozenbeek J, van der Linden S. Good news about bad news: gamified inoculation boosts confidence and cognitive immunity against fake news. Journal of Cognitive Neuroscience. 2020; 3: 2 .

[152] Sepúlveda-Loyola W, Rodríguez-Sánchez I, Pérez-Rodríguez P, Ganz F, Torralba R, Oliveira DV, et al. Impact of social isolation due to COVID-19 on health in older people: mental and physical effects and recommendations. Journal of Nutrition, Health \& Aging. 2020; 24: 938-947.

[153] Crum AJ, Jamieson JP, Akinola M. Optimizing stress: an integrated intervention for regulating stress responses. Emotion. 2020; 20: 120-125.

[154] Christakis NA, Fowler JH. Social contagion theory: examining dynamic social networks and human behavior. Statistics in Medicine. 2013; 32: 556-577.

[155] Zhou F, Yu T, Du R, Fan G, Liu Y, Liu Z, et al. Clinical course and risk factors for mortality of adult inpatients with COVID19 in Wuhan, China: a retrospective cohort study. Lancet. 2020; 395: 1054-1062.

[156] Lunn P, Belton C, Lavin C, McGowan F, Timmons S, Robertson D. Using behavioural science to help fight the coronavirus. ESRI Working Paper No. 656. 2020.

[157] Andrade C. COVID-19: humanitarian and health care crisis in a third world country. Journal of Clinical Psychiatry. 2020; 81: 20com13383.

[158] Christakis NA, Fowler JH. Social network sensors for early detection of contagious outbreaks. PLoS ONE. 2010; 5: e12948.

[159] Kim DA, Hwong AR, Stafford D, Hughes DA, O’Malley AJ, Fowler JH, et al. Social network targeting to maximise population behaviour change: a cluster randomised controlled trial. Lancet. 2015; 386: 145-153.

[160] Ogen Y. Assessing nitrogen dioxide $\left(\mathrm{NO}_{2}\right)$ levels as a contributing factor to coronavirus (COVID-19) fatality. Science of the Total Environment. 2020; 726: 138605.

Abbreviations: ACE-2, angiotensin-converting enzyme 2; COVID-19, coronavirus disease-19; SARS-CoV-2, severe acute respiratory syndrome coronavirus-2; WHO, world health organisation.

Keywords: COVID-19; SARS-CoV-2; Therapeutics; Vaccine development; Socio-economic impacts; Phronetic needs for COVID-19

Send correspondence to: Sintu Kumar Samanta, Department of Applied Sciences, Indian Institute of Information Technology Allahabad, 211012 Allahabad, India, E-mail: samantasintu@iiita.ac.in

$\dagger$ These authors contributed equally. 